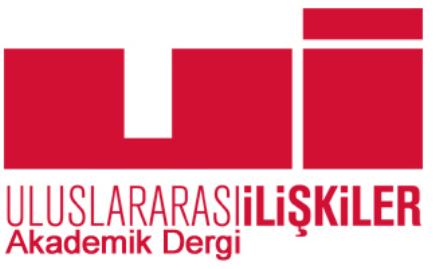

Yayın ilkeleri, izinler ve abonelik hakkında ayrıntılı bilgi:

E-mail: bilgi@uidergisi.com.tr

Web: www.uidergisi.com.tr

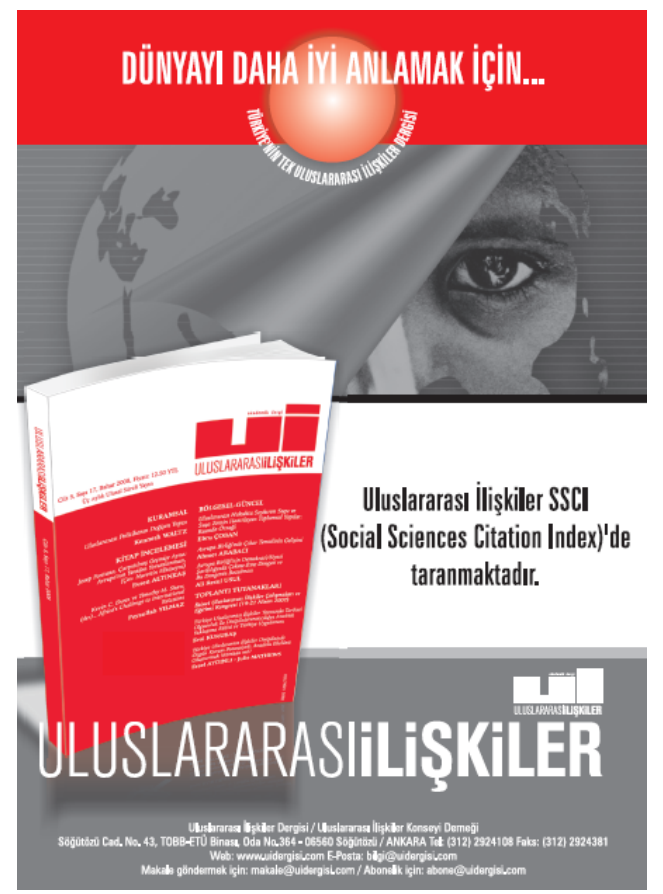

\title{
Reel Politiği Stnırlandıran Kamuoyu: Nükleer İran Örneği
}

\author{
Onur OKYAR* ve İsmail Dinçer GÜNEŞ** \\ * Yrd. Doç. Dr., Uluslararası İlişkiler Bölümü, Çankırı \\ Karatekin Üniversitesi \\ ** Doç. Dr., Kamu Yönetimi Bölümü, Uludağ Üniversitesi
}

Bu makaleye atıf için: Okyar, Onur ve Güneş, İsmail Dinçer, "Reel Politiği Sinirlandıran Kamuoyu: Nükleer İran Örneği", Uluslararası İlişkiler, Cilt 13, Sayı 50, 2016, s. 77-100.

Bu makalenin tüm hakları Uluslararası İlişkiler Konseyi Derneği'ne aittir. Önceden yazılı izin alınmadan hiç bir iletişim, kopyalama ya da yayın sistemi kullanılarak yeniden yayımlanamaz, çoğaltılamaz, dağıtılamaz, satılamaz veya herhangi bir şekilde kamunun ücretli/ücretsiz kullanımına sunulamaz. Akademik ve haber amaçlı kısa alıntılar bu kuralın dışındadır.

Aksi belirtilmediği sürece Uluslararası Illişkiler'de yayınlanan yazılarda belirtilen fikirler yalnızca yazarına/yazarlarına aittir. UİK Derneğini, editörleri ve diğer yazarları bağlamaz. 


\title{
Reel Politiği Sınırlandıran Kamuoyu: Nükleer İran Örneği
}

\author{
Onur OKYAR \\ Yrd. Doç. Dr., Uluslararası Ilişkiler Bölümü, İIBF, Çankırı Karatekin Üniversitesi, Çankırı. \\ E-posta: onurokyar@karatekin.edu.tr \\ İsmail Dinçer GÜNEŞ \\ Doç. Dr., Kamu Yönetimi Bölümü, İİBF, Uludağ Üniversitesi, Bursa. \\ E-posta: ismaildincer@yahoo.com
}

\begin{abstract}
ÖZET
Bu çalışma İran Devletinin/Rejiminin reelpolitik dış politika pratiğinin, daha fazla temel hak ve özgürlükten yana -çalışmada seçili- İran kamuoyu tarafından sınırlandıııldığı ve böylece uluslararası arenada bir dehşet dengesinin yaşanmasının önüne geçildiği hipotezi üzerine bina edilmiştir. Çalışmanın amacı İran kamuoyunun dış politik konulardaki algı ve görüşlerinin Rejimin dış politikasını etkileyip etkilemediğini sorgulamaktır. Bu amaca ulaşmak üzere çalışmanın literatür taraması bölümünde reelpolitiğin ne olduğu ayrıntılı olarak tanımlanmış; kamuoyu ve dış politika ilişkisi ise kuramsal ve tarihi veriler ışığında tartışılmıştır. Bu başlık altında İran'daki kamuoyu araştırmalarının sonuçları da paylaşılarak günümüz İran politik resmi gözler önüne serilmeye çalışılmıştır.
\end{abstract}

Anahtar Kelimeler: İran Rejim ve Kamuoyu, Reelpolitik, Nükleer Güç ve Silah, Temel Hak ve Özgürlükler.

\section{The Public Opinion that Restricts the Real Politics: The Case of Nuclear Iran}

\begin{abstract}
This study is based on the hypothesis that Iranian State's real-political foreign policy practice is constrained by the public opinion which demands more rights and freedoms, thus preventing a balance of violence in the international arena. The introduction explains why Iranian foreign policy is on a real-political axis. The main goal of the study is to question whether the opinion of Iranian public on foreign policy issues affects the Regime's foreign policy. For this purpose in the literature review, a detailed definition of real politics is provided, a chronological analysis of different perspectives is made and a theoretical conclusion is given. Following this, the relation between public opinion and foreign policy is discussed. Iranian public poll results are also discussed to draw a picture of contemporary Iranian politics.
\end{abstract}

Keywords: Iranian Regime and Public Opinion, Realpolitik, Nuclear Power and Weapons, Basic Rights and Freedoms. 


\section{Giriş}

$\mathrm{Bu}$ çalışma İran Devletinin/Rejiminin reelpolitik dış politika pratiğinin İran kamuoyu tarafından daha fazla temel hak ve özgürlükten yana -çalışmada seçili- İran kamuoyu tarafından sınırlandırıldığı ve böylece uluslararası arenada bir dehşet dengesinin ${ }^{1}$ yaşanmasının önüne geçildiği hipotezi üzerine bina edilmiştir. Çalışmanın amacı İran kamuoyunun dış politika konularındaki algı ve görüşlerinin Rejimin dış politikasını etkileyip etkilemediğini sorgulamaktır. Bu bağlamda çalışmada İran'ın reelpolitik dinamikleri ve uygulama analizinden ziyade kamuoyunun dış politikaya etkisi, yapılan alan araştırması marifetiyle, tartışılmıştır.

Çalışmada kamuoyundan kasıt, örneklem dâhilindeki evrenimizdir. Bu örneklemin yüksek eğitim düzeyi, hem çalışmanın bir sınırlılı̆̆g hem de dış politika gibi uzmanlık isteyen bir alandan en net cevapların alınabilmesi için bir gerekliliğidir. Bununla birlikte bulguların daha az kozmopolit yerleşim birimleri ile eğitim seviyesi daha düşük örneklem grupları içerisinde farklılıklar gösterebileceği de dikkate alınmalıdır.

Çalışmanın önemi; kullanılan değişkenlerin İran coğrafyasındaki yansımalarının analitik anket tekniği kullanılarak, yerinde yapılan bir alan araştırmasıyla ölçülmesinden ve literatüre yeni bir veri kazandırmasından kaynaklanmaktadır. Çalışma örneklemi dâhilindeki İran kamuoyunun nükleer güç ve nükleer silah algıları ile uluslararası aktörlere güven dereceleri analiz edilerek İran Rejiminin reelpolitik pratiklerindeki sınırlanma ihtiyacı tartışılacaktır. Çalışmanın literatür ile bulgular bölümleri kendi içlerinde tümevarımsal çıkarımlarla yorumlanmışken sonuç bölümü ise hem literatür hem de bulguların tümdengelim yöntemiyle birleştirilerek spesifik çıkarımlara ulaşılmasıyla sonlandırılmıştır.

Çalışmada İran dış politiğinin reelpolitik eksenli olduğu ön kabulü ile analiz ve yorumlar tartışılmıştır. Zira İran Devrimiyle birlikte İran dış politikası Humeyni tarafından Bağlantısızlık ve Devrim İhracı ilkelerine dayandırılmasına rağmen² uluslararası dini ve/veya mezhebi birlikteliği temel alan İran dış politika stratejilerine uymayan rejimlere sahip Sovyet Rusya, Batı Avrupa, Japonya ve Çin gibi devletlerle yakın ilişkiler tesis edilmiş; bu bağlamda hukuken (nüfusunun \%85'i Şii) Azerbaycan'a ait Dağlık Karabağ'da Ruslarla işbirliği yapılmış, ${ }^{3}$ Müslüman Çeçenistan ve Doğu Türkistan halklarına karşı ise Çin ve Rusya politikaları desteklenmiştir. ${ }^{4}$ Bununla birlikte İran, Arap Baharı sürecinde Tunus, Mısır ve Yemen gibi ülkelerdeki hareketleri İran Devrimi’nden ilham alan bir İslami Uyanış olarak görmüş; fakat Libya'daki isyanları da İslami Uyanış olarak görmesine ve Kaddafi'yi kınamasına rağmen Batının asıl amacının Libya petrolünü sahiplenmek olduğunu belirtmiş ${ }^{5}$ ve bölgeye yapılacak

1 Nükleer silahlı ülkelerin yapacakları bir nükleer saldırıda kazanan tarafın olmayacağı, dünya barış ve güvenliğinin tehlikeye gireceği yargısı üzerine temellendirilen bu kavramla ilgili günümüzde hala güncelliğini yitirmeyen önemli bir kaynak için bkz. A. J. C. Edwards, Nuclear Weapons, the Balance of Terror, the Quest for Peace, New York State University Press, 1986. Ayrıca nükleer silahların yayılmasını önleme ve silahsızlanma faaliyetlerinin artması gerektiğini, nükleer caydırıcılık fenomeninin aslında nükleer savaş riskini daha da arttırdığını savlayan görüşleri için bkz. David Yost, “Analysing International Nuclear Order", International Affairs, Cilt 83, No.3, 2007, s.549-574.

2 Eva Patricia Rakel, "Iranian Foreign Policy since the Iranian Islamic Revolution: 1979-2006", Perspectives on Global Development and Technology, Cilt 1, No.6, 2007, s.160.

3 Soner Cagaptay ve Alexander Murinson, “Good Relations between Azerbaijan and Israel”, 30 Mart 2005, http:// www.washingtoninstitute.org/policy-analysis/view/good-relations-between-azerbaijan-and-israel-a-model-for-othermuslim-state (Erişim Tarihi: 19 Mart 2016), s.1.

4 Hongda Fan, "China's Policy Options towards Iran”, Journal of Middle Eastern and Islamic Studies, Cilt 5, No.1, 2011, s.45-60.

5 Ramin Mehmanparast, "US, NATO After Libya Oil Reserves: Iran”, 29 Nisan 2011, http://edition.presstv.ir/ detail/177586.html (Erişim Tarihi: 19 Mart 2016), s.1. 
bir askeri müdahaleye şiddetle karşı çıkmıştır. İran'a göre Suriye'deki savaş ise Batının bir komplosudur. Rejimin meşruiyetinin korunması, alternatif baharlara karşı İran kamuoyuna bir mesaj verilmesi ve dış politikada Şii Hilali'nin desteklenmesi maksatlarıyla İran; Suriye’ye açıtan askeri, ekonomik ve diplomatik destekte bulunmuş, Kudüs Gücü ve Hizbullah, Esed için Suriye' deki Müslüman “isyancılarla” savaşmıştır. ${ }^{6}$ Tüm bu verilerden hareketle çalışmada İran dış politikasının reelpolitik temelli olduğu kabul edilmiştir. Bu ifadeden kasıt, ülkelerin dış politikaları dolaylı veya dolaysız biçimde reelpolitik temelli gelişmekteyse de, sui generis İran dış politikasının teopolitik odaklı ve klasik reelpolitik temelli olduğudur.

Çalışmanın literatür taraması bölümünde reelpolitiğin ne olduğu ayrıntılı biçimde tanımlanarak tarihten günümüze bu kavramla ilgili düşünür ve yazarların görüşleri kronolojik bir sıralamayla incelenmiş ve kuramsal bir sonuca ulaşılmıştır. Bu başlığın ardından kamuoyu ve dış politika ilişkisi kuramsal ve tarihi veriler 1şı̆̆ında tartışılmıştır. İlgili tartışmalar literatürde daha çok ABD örneği üzerinden incelenmesine rağmen bu başlık altında İran'daki kamuoyu araştırmalarının sonuçları da paylaşılarak günümüz İran politik resmi gözler önüne serilmeye çalışılmıştır. Bu bölüm ile hem günümüze kadar yapılmış ilgili çalışmaların sonuçları paylaşılarak literatüre bir katkı sağlanmış hem de bu çalışmalardan elde edilen sonuçların makalenin verileriyle olan uyumu ortaya konularak çalışmanın geçerliliği artırılmıştır. Çalışmanın önemini de haiz veri-yöntem kısmı ise çalışmanın örneklemi bağlamında tüm İran kamuoyunun genel bir resmini çıkarmak amacıyla sosyo-demografik bağımsız değişkenlerin ilgili bağımlı değişkenlerce analizi sonuçlarını içermektedir.

\section{Reelpolitik Nedir?}

Reelpolitik kavramı realizm kavramıyla iç içe geçmiş olmakla birlikte reelpolitik, iç ve dış politika yapım sürecindeki kararalıcıların pratikleri iken realizm bu pratiklerinalınma sebeplerini inceleyen bir teoridir. Çalışmada da reelpolitik ile kast edilen İran'ın cari iç ve dış politika pratikleridir. $\mathrm{Bu}$ bağlamda siyasi gerçekçilik veya güç politikası olarak da ifade edilebilecek reelpolitik, uluslararası ilişkilerin en eski ve en çok kabul gören yaklaşımlarındandır.7 Devletlerarası ilişkiler/ çatışmalar sürecinde devlet eylemlerinin uluslararası politikaya uygulanabilirliği bakımından en yüksek öngörü potansiyeline sahip olan reelpolitik, güç ve hayatta kalma amacına yönelik politika üretme kuramı olarak tanımlanabilir. ${ }^{8}$ Almancadan türetilmiş olan bu terim teorik veya etik amaçlardan ziyade pratik ve maddi faktörlere dayalı bir siyaset anlamına da gelmektedir. ${ }^{9}$

Reelpolitik, özellikle 21. yüzyılın uluslararası politik zorluklarıyla alakalı olarak son 160 yılda tanınamayacak kadar istismar edilmiş bir kavramdır. ${ }^{10} \mathrm{Bu}$ bağlamda kavramın neyi ifade ettiği konusunda literatürde bir anlayış karmaşası vardır. Zira 19. yüzyıl ile birlikte ortaya çıkan özgürlük ve hızlı sanayileşme sonucu toplumsal düzen, sınıf savaşları, mezhepçilik ve milliyetçiliğin yükselişi ile gelişen güç mücadeleleri kavramın yapısında evirilmeye yol açmıştır. Hatta bu kavram günümüzde modernitenin ikilemlerine yanıt olarak dahi

6 Mohammad-Reza Djalili ve Thierry Kellner, Arap Baharı Karşısında İran ve Türkiye, İstanbul, Bilge Yayınevi, 2013, s.69-74.

7 Jack Donnelly, "Realism”, Scott Burchill et.al. (der.), Theories of International Relations, New York, Palgrave Macmillan, 2005, s.29.

8 Murielle Cozette, "Realistic Realism? American Political Realism, Clausewitz and Raymond Aron on the Problem of Means and Ends in International Politics", Journal of Strategic Studies, Cilt 27, No.3, 2004, s.428.

9 Gordon Anderson, "Realpolitik and World Peace", International Journal on World Peace, Cilt 26, No.4, 2009 , s.3.

10 John Bew, “The Real Origins of Realpolitik”, Mart/Nisan 2014, http://nationalinterest.org/article/the-real-originsrealpolitik-9933 (Erişim Tarihi: 19 Mart 2016), s.42. 
kullanılmıştır. ${ }^{11} \mathrm{Bu}$ noktadan hareketle reelpolitik, geleneksel güç paradigmasının temelindeki belirsizlik ve düzensizlik çabalarını yönetmek için ortaya atılmış Hobbes'çu bir alandır. ${ }^{12}$ Belirsizlik ve düzensizliğin temel sebebi insanın ahlaki gelişme ve imkânları konusunda kötümserlik üzerine kimliklenmesinden kaynaklanmaktadır. ${ }^{13} \mathrm{Bu}$ bağlamda realistler için insan doğası Tukididis (Thucydides) örneğinden bu güne değişmemiş ve değişmeyecektir. ${ }^{14}$ Bu nedenle çıkarların güç ile korunması zaman üstü evrensel bir yasadır. Çıkarlar ise Vestfalya Sistemi'nden itibaren ulus devletin ve/veya etnik grupların korunmasında kullanılagelmiştir. ${ }^{15}$

Devletlerin reelpolitiği esas alan pratikleri sonucunda ülke içinde büyüyen belirsizlik ve yönetime olan güvensizlik ise otoriter politikaların artmasına sebep olacak; var olan demokratik yap1 daha kaotik bir hale gelecektir. Bu anarşik ortam, ironik bir şekilde, rejimin güvenlik ve düzen çabaları için daha fazla antidemokratik ve kuvvet tabanlı önlemler almasına ve böylece oluşan güvenlik ikilemi ise sistemin çöküşüne dahi sebep olabilecektir. ${ }^{16}$ Dolayısıyla en sert reelpolitik pratik, ulus içinde diktatorya, yapısal, kültürel ve fiziksel şiddet içeren (soykırım dâhil) politikalarla statükonun savunulması ve idamesidir. ${ }^{17}$

Bu bağlamda hegemonya, güç ve çıkar ekseninde Sparta ve Pers ortaklığıyla Atina’ya karşı mücadelesini açıklamaya çalışan Tukididis, reelpolitiğin ilk yorumlayıcılarındandır. ${ }^{18}$ Zira o "güçlü olan daima haklıdır ve ben güçlüyüm." diyen Atina'nın politikalarına karş1 ${ }^{19}$ bir "gereklilik" olarak önleyici müdahale mantığıyla savaşı başlatan taraf olmuştur. ${ }^{20}$

Tarihte reelpolitiği sistematik hale getirmiş olduğu varsayılan Makyavelli, insan doğasından hareketle siyasal kurumlar ve liderliği Virtu ve Fortuna kavramlarıyla açıklamaya çalışır; Virtu bilgelik/kurnazlık anlamına gelir, Fortuna ise talih/belirsizliktir. ${ }^{21}$ Lider iktidara gelebilmek için Virtu'yu temel alır; Fortuna'ya hâkim olabilmek içinse güç ve çıkar temelli ikiyüzlü bir yönetim öngörmelidir. ${ }^{22} \mathrm{Bu}$ yönetimde din, hâkimiyetin meşrulaştırılmasında başvurulan bir araç hükmündedir. ${ }^{23}$ Zira din, devletin/rejimin devamını sağlamaya yaradığ müddetçe değerlidir. Bu bağlamda bir devlet reelpolitik hedefler doğrultusunda uluslararas1 arenada ittifaklar geliştirmek için ortak miras kullanabilir. Ortak bir dini arka plan kullanılarak

11 Ibid.

12 Dennis Sandole, “Complexity and Conflict Resolution”, Neil Harrison (der.), Complexity in World Politics: Concepts and Methods of a New Paradigm, Albany, State University of New York Press, 2006, s.43.

13 Robert Gilpin, "The Richness of the Tradition of Political Realism”, Robert Keohane (der.), Neorealism and its Critics, New York, Columbia University Press, 1986, s.304.

14 Pettman ise insan doğasının iyi veya kötü olabileceğini hesaplayacak bilimsel bir kıstas olmadığını ve dolayısıyla küresel dünya okumalarında realist veya liberal olmanın bir anlam ifade etmediğini belirtir. Ayrıntılı bilgi için bkz. Ralph Pettman, "Power and Morality: A Misleading Dichotomy", Cambridge Review of International Affairs, Cilt 21, No.2, 2008 , s.240.

15 Sandole, Complexity, s.44.

16 Ibid. s.57.

17 Johan Galtung, "Violence, Peace, and Peace Research”, Journal of Peace Research, Cilt 6, No.3, 1969, s.179.

18 Thucydides, The Peloponnesian War, Oxford University Press, 2009; Paul Rahe, “Thucydides Critique of Realpolitik”, Benjamin Frankel (der.), Roots of Realism: Philosophical and Historical Dimensions, Londra, Frank Cass Press, 1996, s.105-141.

19 James Dougherty ve Robert Pfaltzgraff, Contending Theories of International Relations, Londra, Harper Collins Press, 1990, s.90.

20 Makyavelli'nin teorisinde de aynı önleyici doktrinin izleri vardır. Ayrıntılı bilgi için bkz. Steven Forde, "International Realism and the Science of Politics: Thucydides, Machiavelli and Neorealism”, International Studies Quarterly, Cilt 39, No.2, 1995, s.152 ve 158.

21 Niccolò Machiavelli, The Prince, Oxford University Press, 2005, s.20-29.

22 Quentin Skinner, Machiavelli: A Very Short Introduction, Oxford University Press, 2001, s.62.

23 Machiavelli, The Prince, s.61. 
gelişecek bu dinamikler pozitif manada kooperatif diş politika pratikleriyle neticelenebileceği gibi negatif biçimde yabancı kaynaklı/destekli ayaklanma ve sivil savaşlara da yol açabilir. ${ }^{24}$ Buna karşın, amaç için araçların sınırsızca kullanılması bağlamında ${ }^{25}$ Tanrı' dan korkan halk, prensten de çekinecek ve böylece iktidara aidiyet azalmadan devam edecektir. ${ }^{26}$ Aidiyeti korumanın en önemli aracı ise güçtür. Yöneticinin çıkarları için değil, halkın korunması için yapıldığ 1 "düşünülen” bu politika sonucu halk yönetimden korkacak ve sayg1 duyacak; ama daha fazlasıyla korkacaktır. Zaten Makyavelli için insan hayatı ve dolayısıyla siyaset, savaşın devamıdır. Böylesine anarşik bir evrende devletin devamlılı̆̆ı esas olmalı ve hikmet-i hükümet (raison d'État) çerçevesinde reelpolitik hedefler meşrulaştırılmalıdır.

Hobbes'a göre güçlü, zayıf karşısında haklı olmak için gücü bir araç olarak kullanır. Lakin sistemin güç mücadelesi üzerine temellendirilmesi bizi anarşik bir evrene götürecektir. Bireysel temelde insanlar güç mücadelesini üç temel amaç için yaparlar. İlki rekabettir; çünkü tüm rakipler eşittir. Bu eşitlik aslında rakipler arası güvensizliğin de bir nedenidir. ${ }^{27}$ Böylece karşıdaki rakip temel hak ve özgürlükleri de dâhil göz ardı edilerek elenmelidir. İkincisi güvensizliktir; zira anarşik sistemde korunabilmek için saldırmak gerekmekte ve çatışma süregitmektedir. Üçüncüsü ise zafere ulaşma isteğidir; böylece öteki rakipler yok edilerek zaferin sahibi olunabilecektir. Uluslararası düzene de teşmil edilebilecek bu sistemde anarşik düzeni otorite altında birleştirecek hegemonik bir güç olarak Leviathan'a ihtiyaç vardır; lakin olmadığı için savaş kaçınılmazdır ve sistem savaşın devamıdır. ${ }^{28}$

Makyavelli’nin reelpolitik görüşünü destekleyen Carr'a göre, tarihteki sebep ve sonuçlar hayali/vehmi algılamalarla değil entelektüel bir çabayla anlaşılabilir. Dolayısıyla siyasi teori siyasal pratiğe değil, siyasal pratik siyasi teoriye şekil verir. Bu bağlamda anarşik sistemdeki politikalar etik ilkelere bağlı değildir/olmamalıdır; dahası bu etik ilkeler gücün bir ürünüdürler. ${ }^{29}$ Dolayısıyla çıkarlara ulaşacak politikaların meşrulaştırılmasının yegâne aracı güçtür. Bu güçten kasıt ise devletin yekta çıkarlarını artırmak maksatlı yegâne araçları olan askeri ve politik güç ilişkileridir. ${ }^{30}$

Yaklaşımını İkinci Dünya Savaşının uluslararası ilişkileri değiştirdiği dönemde şekillendirmeye çalışan Schwarzenberger için güç paradigması yeniden şekillenmeye başlamıştır. Aristoteles'in gözlemine göre politik bir hayvan olan insan ${ }^{31}$ için sosyopolitik olayların temel sebebi grup çatışmalarıdır. ${ }^{32}$ Schwarzenberger'e göre de gruplar/devletler, kendilerini Weber'den hareketle- nihai sadık olunması gereken bir varlık olarak gördüklerinden kendilerini korumak için gerekli her türlü tedbiri almakta haklıdırlar. Bu tedbirler bağlamında ortaya çıkacak hukuki ve ahlaki kriterler ise uluslararası ilişkilerin birincil esasları olmamalıdırlar. ${ }^{33}$

24 Carolyn Warner ve Stephen Walker, “Thinking about the Role of Religion in Foreign Policy: A Framework for Analysis”, Foreign Policy Analysis, Cilt 7, No.1, 2011, s.120.

25 Jack Donnelly, Realism and International Relations, Cambridge University Press, 2000, s.25.

26 Skinner, Machiavelli, s.62.

27 Tayyar Arı, Uluslararası İlişkiler Teorileri, İstanbul, Alfa Yayınları, 2002, s.182.

28 Thomas Hobbes, Leviathan, London, Green Dragon Press, 1651, s.76-79.

29 Edward Hallett Carr, The Twenty Years'Crisis,1919-1939: An Introduction to the Study of International Relations, New York, St. Martin's Press, 1946, s.63.

30 Robert Gilpin, “No One Loves a Political Realist”, Security Studies, Cilt 5, No.3, 1996, s.8.

31 James Chester, “Aristotle and the Roots of Individualism”, Douglas Rasmussen et.al. (der.), Reality, Reason, and Rights: Essays in Honor of Tibor R. Machan, New York, Lexington Books, 2011, s.13-26.

32 Ralf Dahrendorf, Class and Class Conflict in Industrial Society, Stanford University Press, 1959.

33 Georg Schwarzenberger, Power Politics: An Introduction to the Study of International Relations and Post-war Planning, London, J. Cape Press, 1941, s.13. 
$\mathrm{Bu}$ bağlamda realizmin modern dönemdeki ilk yorumcusu olan Morgenthau'nun ilkelerine ${ }^{34}$ göre politika, insanların yaptığı objektif yasalar üzerine bina edilmeli; güç, çıkarları maksimize etmek için kullanılmalı; çıkarlar zaman ve mekândan bağımsız olmalı; etik ve ahlak ilkeleri uluslararası ilişkilerde uygulanmamalı ve uluslararası ilişkiler siyasi kriterler temel alınarak tespit edilmelidir. ${ }^{35}$ Waltz ise reelpolitiği sosyolojik temelde inceleyerek temel faktörlerini sıralamıştır. ${ }^{36}$ Bunlara göre yöneticilerin ve sonra devletin hareketinin temeli çıkar sağlamaktır; buna sebep olan politik ihtiyaçlar ise devletlerin düzensiz rekabetinden ortaya çıkar. Böylece devletin çıkarlarına en iyi yarayacak politikalar keşfedilebilir. Politikanın nihai testi olan başarı ise devletin korunması ve güçlendirilmesi olarak tanımlanır. ${ }^{37}$ Lakin Waltz için güç amaç değil gerektiğinde kullanılması gereken bir araçtır. Zira uluslararası anarşik sistemde devletler kendi haklarını savunurlarken aslında bir güç dengesi de kurmuş olurlar. ${ }^{38}$

Güç dengesi; doğanın kanunu, basit bir zorbalık veya yasadışı bir hareket olarak görülebilir. ${ }^{39}$ Kimi devlet için bir kılavuz başkaları içinse kendi emperyalist politikalarını gizleyen bir kisvedir. Bazı devletler için ülkelerinin güvenliği ve dünya barışının en iyi garantisiyken diğerleri içinse savaşların en önemli sebebi olan ve devletleri harap eden bir sorundur. ${ }^{40}$ Morgenthau'ya göreyse devletlerarası güç dengesi yöntemleri dört tanedir. Bunlar silahlanma, ittifak kurma, tazminat isteme/alma, böl ve yönet politikası uygulamaktır. Bu doğrultuda devletlerarası ilişkiler emperyalist, statükocu veya itibar/karizma amaçlı çıkar ilişkilerine dayanmaktadır. ${ }^{41}$ Ahlak ile çıkarın çatışmasında ise devletin varlığını korumak amacıyla çıkar tercih edilmelidir. ${ }^{42}$ Waltz'ın halefi Keohane'e göre de uluslararası politikanın tek rasyonel aktörü devletlerdir. Devletin asıl hedefi çıkar, bu hedefi gerçekleştirmenin temel aracı ise daha fazla güç elde edebilmektir. ${ }^{43}$

Tüm bu verilerden hareketle idealpolitiğin ${ }^{44}$ tersi olan reelpolitiğin kapsamı; "kötü" insanın zararlarına karşı devletlerin zora dayalı ve/veya determinist politika üreterek elde edilen çıktıları -anarşik düzenden hareketle- savaşın bir devamı olarak görmesinde yatmaktadır. Devletler için eşitlik, hukuk, etik, ahlak ve din gibi olguların "görevleri" ise sadece güç ve çıkar maksimizasyonudur. Bassiouni'ye göreyse kamuoyunun bu "zor" konuya vakıf olamaması için devletler gerçeği karartarak kamuoyunu manipüle etmektedirler. ${ }^{45}$ Buna rağmen kamuoyunun özellikle dış politik konulardaki tavrı, devletler için çok önemli bir karar verme aracı olduğu için devletlerin çıkarları, kamuoyu baskısı sonucu, salt reelpolitik hedefler doğrultusunda şekillen(e)memektedir.

34 Hans Morgenthau, Politics Among Nations, New York, Alfred Knopf Press, 1948.

35 Arı, Uluslararası İlişkiler Teorileri, s.188.

36 Gilpin, The Richness of the Tradition, s.302.

37 Kenneth Waltz, Theory of International Politics, Boston: Addison-Wesley Publishing, 1979, s.117.

38 Ibid. s.94.

39 Ayrıntılı bilgi için bkz. Roger Spegele, Political Realism in International Theory, Cambridge University Press, 1996, s.83-101.

40 Waltz, Theory of International Politics, s.117.

41 Morgenthau, Politics Among Nations, s.21-60.

42 Ibid. s.177-178.

43 Robert Keohane, “Theory of World Politics: Structural Realism and Beyond”, Robert Keohane (der.), Neo-Realism and Its Critics, New York, Columbia University Press, 1986, s.164-165.

44 Ayrıntılı bir çalışma için bkz. Jeffrey Legro, Rethinking the World: Great Power Strategies and International Order, New York, Cornell University Press, 2005.

45 Cherif Bassiouni, "Justice and Peace: The Importance of Choosing Accountability over Realpolitik," Case Western Reserve Journal of International Law, Cilt 35, No.191, 2003, s.192. 
Sonuç olarak reelpolitiğin temeli anarşik bir uluslararası evrende -dini, ahlaki, etik veya hukuki değil- somut çıkarların maksimize edilmesine dayanır. Buna karşı rejimler hangi tür olursa olsun- hâkimiyetlerini korumak için günümüzde kamuoyunu dikkate almak zorundadırlar. Kamuoyunun rejim üzerindeki bu baskısı rejimlerin mutlak reelpolitiği esas almalarına engel olmakta ve devletlerin dış politikalarında salt çıkar temelli politikalar üretmelerinin önüne geçmektedir.

\section{Kamuoyu-Dış Politika İlişkisi ve İran}

İkinci Dünya Savaşı’nın sonuna kadar dış politika konularında kamuoyunun ilgisiz ve bilgisiz olduğu çıkarımları yapılmıştır. ${ }^{46}$ Buna göre dış politik konular gündelik hayatını ikame ettirmeye çalışan birey için çok uzak ve kendine göre önemsiz konulardır. ${ }^{47}$ Toplum, devletin dış politik tutumlarına karşı ilgisiz ve bilgisiz olduğu için hükümetlerin sokaktaki insanın alg1sal/duygusal tercihlerini dikkate almaları tehlikeli bile olabilecek vahim hatalara sebep olabilir. Bu yüzden hükümetler duygudan uzak ve akılcı kararlar almalıdırlar. Vietnam Savaşı'nda ABD’nin resmi dış politika yaklaşımı uluslararası ilişkilerde bir dönüm noktası olmuş, bu tarihten itibaren kamuoyunun dış politikayla ilgili duygu ve düşüncelerinin dış politika yapımında önemli bir yeri olduğu -ülke, rejim, din/mezhep, kültür vs. farkı gözetmeksizin- kabul edilmiştir. ${ }^{48}$

Bu bağlamda uluslararası ilişkiler disiplini Soğuk Savaş’ın sona ermesiyle birlikte, dış politikanın kurumsal ve toplumsal kaynaklarını revize ederek dış politikayı açıklamak için iç siyaseti de analiz etmeye başlamıştır. Bu dönemde kamuoyunun mantıklı olsun veya olmasın dış politikayı etkileyebileceğini, kamuoyunun oluşumu üzerinde özellikle medyanın rolünün baskın olduğunu, siyasi elitlerin tutum ve eylemlerinin dış politikayı asıl etkileyen faktör olduğunu savunan görüşler tartışılmıştır. ${ }^{49}$

Günümüzde ise literatürde kamuoyu-dış politika ilişkisini inceleyen çalışmalar arasında önemli kırılma noktaları bulunmaktadır. Bu bağlamda kamuoyunu çeşitlendiren sosyodemografik faktörler ile dış politika sürecinde politika yapıcılar tarafından verilen kararlar arasında herhangi bir bağıntının olup olmadığı, ilgili yazında genel olarak, ABD özelindeki çalışmalar ile açıklanmıştır. ${ }^{50} \mathrm{Bu}$ analizler neticesinde kamuoyunun diş politikadaki etkisinin

46 Birinci Dünya Savaşı sonrası için bkz. Walter Lippmann, Public Opinion, New Jersey, Transaction Publishers, 1922; İkinci Dünya Savaşı sonrası için bkz. Gabriel Almond, The American People and Foreign Policy, New York, Harcourt, Brace and Company Press, 1950.

47 Özellikle Morgenthau’nun bu savunusu insanın doğasında kötü bir varlık olduğu ön kabulü ile de uyumludur. Diğer bir kaynak için bkz. George Kennan, American Diplomacy: 1900-1950, Dublin, Mentor Books, 1970.

48 Richard Sobel, The Impact of Public Opinion on U.S. Foreign Policy since Vietnam, Oxford University Press, 2001; Ole Holsti, "Public Opinion and Foreign Policy: Challenges to the Almond-Lippmann Consensus Mershon Series: Research Programs and Debates", International Studies Quarterly, Cilt 36, No.4, 1992, s.445-446. Ayrıca bkz. Benjamin Page ve Robert Shapiro, "Effects of Public Opinion on Policy", American Political Science Review, Cilt 77, No.1, 1983, s.175-190; Douglas Foyle, Presidents, Counting the Public In: Public Opinion, and Foreign Policy, New York, Columbia University Press, 1999.

49 Ayrıntılı bilgi için bkz. Wu Chengqiu, "International Structure, Threat, and Public Opinion on Foreign Policy: Bush and Obama's Foreign Policy Turns”, The Chinese Journal of International Politics, Cilt 4, No.3, 2011, s.320-322.

50 Onur Okyar, “İran ve Arap Baharı: Çift Taraflı Aynadaki Asimetri mi?”, Uluslararası İlişkiler Dergisi, Cilt 12, Sayı 45, 2015, s.61-82. 
sınırlı olduğu ifade edilse de ${ }^{51}$ Batı literatürünün yenilikçi görüşleri' ${ }^{52}$ kamuoyunun ülkelerin dış politika retorik ve pratiklerini yüksek oranda etkilediğini kabul etmektedir.

ABD özelindeki çalışmalara karşın İran Rejiminin kapalı yapısı İran kamuoyunun dış politika konularındaki bakışını ölçmek amacıyla saha çalışması yapılmasını neredeyse imkânsız kılmıştır. Bununla birlikte İran'da özellikle Soğuk Savaş'ın sona ermesinden itibaren devletin stratejik vizyonu ile ilgili resmi ve özel araştırma enstitülerince çalışmalar yapılmaya; kamuoyu tartışmalarına yön veren gazetelerde de ulusal güvenlik ve silahsızlanma ile ilgili güncel haber ve yorumlar yapılarak yayımlanmaya başlanmıştır. ${ }^{53}$

Buna rağmen alan araştırması yapmaya çalışan reformist bir gazeteci, yaptığı çalışmanın Amerikan finansörlerince desteklendiği iddiasılla tutuklanmış ve 2002-2010 yılları arasında hapis cezası ile cezalandırılmıştır. ${ }^{54}$ Dolayısıyla İran' da Anti-Amerikancılık Hatemi döneminde sessizliğe bürünse de Ahmedinejad ile birlikte 1979 Devrimi’nin bir mirası olarak yeniden canlanmıştır. Lakin Ahmedinejad'ın reelpolitiğine rağmen Rehber'in dengeleme siyaseti sayesinde İran'ın içişlerine ABD müdahalesini önlemek ve AB ülkeleri ile İran'ın ekonomik ilişkilerini genişletmek amacıyla ${ }^{55}$ Ruhani’nin cumhurbaşkanlığına onay verilmiş, İran'ın siyasi şeffaflığının sağlanması adına da önemli bir adım atılmıştır. Zira İran Rejimi Batıyla ilişkilerinde pragmatik/reelpolitik eksenli olmasının yanında kendi içinde de en önemli gücün sivil toplum ve kamuoyu olduğunun farkına varmaya başlamıştır. ${ }^{56}$

Bu doğrultuda kapalı ve otokratik Rejimin nispi olumsuzluklarına rağmen İran' da sınırlı da olsa alan çalışmaları yapılmaya başlanmıştır. ${ }^{57}$ Günümüz Cumhurbaşkanı ve dönemin Ulusal Güvenlik Yüksek Konseyi Sekreteri Ruhani gibi çeşitli devlet temsilcileri tarafindan yapılan açıklamalara göre İran kamuoyunun diş politik (özellikle nükleer) konularda çok hassas olduğu ve dolayısıyla Rejimin hem iç hem de dış politikada halkın desteğini alması gerektiği ifade edilmiştir. ${ }^{58}$

51 James McCormick, American Foreign Policy and Process, Boston, Wadsworth Press, 2010, s.577-585; Paul Burstein, "The Impact of Public Opinion on Public Policy”, Political Research Quarterly, Cilt 56, No.1, 2003, s.29-40.

52 Benjamin Goldsmith ve Yusaku Horiuchi, "In Search of Soft Power: Does Foreign Public Opinion Matter for U.S. Foreign Policy?”, World Politics, Cilt 64, No.3, 2012, s.555-585; Ole Holsti, Public Opinion and American Foreign Policy, Michigan, The University of Michigan Press, 2004, s.36-40; Eugene Wittkopf, Christopher Jones ve Charles Kegley, American Foreign Policy: Pattern and Process, Belmont, Thomson Wadsworth Press, 2004, s.241-280; Stuart Soroka, "Media, Public Opinion, and Foreign Policy", The International Journal of Press/Politics, Cilt 8, No.1, 2003, s.27-48.

53 21. yüzyıldaysa bu hareketler siyasete daha çok adapte olmaya başlamışlardır. Bkz. Shannon Kile, Europe and Iran: Perspectives on Non-proliferation, SIPRI Research Report No 21, Oxford University Press, 2005, s.84.

54 Nazgol Ashouri, “Polling in Iran: Surprising Questions”, 14 May1s 2003, https://www.washingtoninstitute.org/policyanalysis/view/polling-in-iran-surprising-questions (Erişim Tarihi: 19 Mart 2016), s. 1.

55 Rakel, Iranian Foreign Policy, s.181-182.

56 Farideh Farhi, "Atomic Energy Is Our Assured Right: Nuclear Policy and the Shaping of Iranian Public Opinion", Judith Yaphe (der.), Nuclear Politics in Iran, Washington, National Defense University Press, 2010, s.4.

57 Zogby Research, "Iranian Attitudes Report”, Aralık 2013, http://www.zogbyresearchservices.com/index/\#/iranianattitudes-2013/ (Erişim Tarihi: 19 Mart 2016); Terror Free Tomorrow, "Polling Iranian Public Opinion Report”, Haziran 2007, http://www.terrorfreetomorrow.org/upimagestft/TFT\%20Iran\%20Survey\%20Report.pdf (Erişim Tarihi: 19 Mart 2016); Steven Kull, "Public Opinion in Iran”, 24 Ocak 2007, http://www.worldpublicopinion.org/ pipa/pdf/apr08/Iran_Apr08_rpt.pdf (Erişim Tarihi: 19 Mart 2016); Michael Herzog, "Iranian Public Opinion on the Nuclear Program", 1 Haziran 2006, https://www.washingtoninstitute.org/uploads/Documents/pubs/PolicyFocus56. pdf (Erişim Tarihi: 19 Mart 2016). 2012 yılına kadar İran'da yapılmış kamuoyu araştırmaları ve içerikleri için bkz. Ehsan Shahghasemi, et.al., "How do Iranians and U.S. Citizens Perceive Each Other: A systematic Review", Journal of Intercultural Communication, Say1 27, 2011.

58 Hasan Ruhani, "Beyond the Challenges Facing Iran and the IAEA Concerning the Nuclear Dossier”, 30 Eylül 2005, http://www.iranwatch.org/sites/default/files/rahbord-rohani-093005_0.pdf (Erişim Tarihi: 19 Mart 2016). 
Bununla birlikte bilgi ve iletişim teknolojisindeki yeni gelişmeler ile İran kamuoyunun politik farkındalığının artması, Rejim tarafından kamuoyunun alg1 ve düşüncelerinin ölçülmesi ihtiyacını da gündeme getirmiştir. ${ }^{59}$ Rejimin bu ihtiyacının temel sebebi, özellikle Arap Baharı hareketleri ile sosyal medyayı çok etkin kullanan genç nüfusun sosyopolitik bir aktör haline dönüşmesidir. ${ }^{60} \mathrm{Bu}$ dönüşüm yekvücut olarak hareket edebilme yetisi kazandıran sosyal medyanın önemli bir kamuoyu aracı olduğunu da ortaya çıkarmıştır. ${ }^{61}$ Örneğin, 2009'daki şaibeli Cumhurbaşkanlığı seçiminin gözden geçirilmesi ve sonuçlanana kadar sokakta kalınması şeklinde özetlenecek isteklerle başlatılan ve Yeşil Hareket olarak tanımlanan bir bahar provası Arap Baharından önce İran'da örgütlenmiştir. ${ }^{62}$ Aralarında Kürt, Beluç, Arap gibi farklı etnisitelerin de yer aldığ 1 halk, sosyal medya üzerinden bu harekete katılsa da yetersiz ideolojik altyapı ve Rejimin sıkı güvenlik tedbirleri nedeniyle etkili olunamamıştır. ${ }^{63}$

$\mathrm{Bu}$ gelişmelerden hareketle 2002 yılında İran Parlamentosunun Ulusal Güvenlik Komitesi tarafından yaptırılan bir ankete göre İranlıların \%46'sı ABD'nin İran politikalarını "bir ölçüde" doğru bulmaktayken 15 yaşın üzerindeki" ${ }^{64}$ İranlıların \%74'ü ABD ile ilişkilerin yeniden başlatılması gerektiğini belirtmişlerdir. ${ }^{65}$ İran genelinde 2007 yılında 1.000 kişiyle tesadüfi örnekleme yöntemi ile yapılan bir telefon anketinde ${ }^{66}$ ise katılımcıların $\% 68$ 'i Filistin Devleti ile birlikte İsrail'in de tanınması ve ABD ile İran arasındaki ilişkilerin normalleşmesi tercihinde bulunmuşlardır. ${ }^{67}$

İran'da 2004 yılında nükleer güç konusunda yapılan bir anket ile İranlıların silahlanma ve nükleer teknolojiye erişim arasında bir ayrım yaptığı, İranlıların nükleer silaha sahip olmak istemediği ve bunun İran'1 daha da güvensiz hale getireceği sonuçlarına varılmıştır. ${ }^{68} 2007$ yılında ise 1.000 katılımcılı ve tesadüfi örnekleme yöntemiyle yapılan bir telefon anketinin ${ }^{69}$ sonuçlarına göre İranlıların sadece \%29'u nükleer silah geliştirmenin İran hükümeti için çok önemli bir öncelik olduğunu \%88'i ise İran ekonomisinin iyileştirilmesinin en öncelikli konu olduğunu belirtmişlerdir. ${ }^{70}$ Aynı çalışmada katılımcıların \%78'i İran'da nükleer enerjinin geliştirilmesini desteklerken sadece \%33'ü nükleer silah geliştirilmesi gerektiği görüşündelerdir. ${ }^{71} 2009$ yılında bir Türk araştırma şirketi taşeronluğunda 1.002 katılımcıyla ve tesadüfi örnekleme yöntemiyle yapılan bir telefon anketine göreyse; katılımcıların \%98'i

59 Shannon, Europe and Iran, s.83.

60 Michael Hardt ve Antonio Negri, “Arabs are Democracy’s New Pioneers”, 24 Şubat 2011, http://www.theguardian. $\mathrm{com} /$ commentisfree/2011/feb/24/arabs-democracy-latin-america (Erişim Tarihi: 19 Mart 2016).

61 Robert Kaplan, The Revenge of Geography, New York, Random House Press, 2012, s.24.

62 Michael Axworthy, A History of Iran, New York: Basic Books, 2008, s.299.

63 Okyar, Iran, s.65.

64 Kamuoyunu oluşturan nüfusun yarısından fazlasının Devrimden sonra doğmuş olmasından dolayı, Devrim sırasında yaygın olan Amerikan/Batı karşıtı duygular "küreselleşmiş” yeni nesilde karşılık bulmamaktadır. Shahram Akbarzadeh, "Democracy Promotion versus Engagement with Iran”, Journal of Contemporary Asia, Cilt 41, No.3, 2011, s.477.

65 Ashouri, Polling in Iran, s.3.

$66 \mathrm{Bu}$ dönemde devletin tüm telefon konuşmalarını dinlediğiyle ilgili sürekli bir endişe olmasına rağmen çalışmadaki oranlar dikkat çekicidir.

67 Terror Free Tomorrow Report, 2007.

68 Trita Parsi, “Tharwa Feature: Iranian Public Opinion and Tehran's Nuclear Program”, 4 Nisan 2005, http://www. tharwaproject.com/node/1902 (Erişim Tarihi: 19 Mart 2016).

69 Terror Free Tomorrow Report, 2007.

70 Başka bir alan araştırmasında katılımcıların \%28’i İran Cumhurbaşkanlığı seçimlerinde en belirleyici/önemli sorun olarak ekonomiyi görmüşlerdir. Sara Beth Elson ve Alireza Nader, What Do Iranians Think? A Survey of Attitudes on the United States, the Nuclear Program, and the Economy, Santa Monica, RAND Institute Press, 2011, s.3.

71 Terror Free Tomorrow, 2007, s.3. 
nükleer enerjinin kullanımının İran için bir hak olduğu konusunda hemfikirdirler. ${ }^{72}$ Lakin nükleer silah konusunda görüşler farklılaşmaktadır. Katılımcıların \%46'sı nükleer silah geliştirilmesine karşıyken \%43'ü nükleer silah geliştirmenin İran için ulusal bir hak olduğunu belirtmişlerdir. Bu sonuç ilginçtir; zira İran otoriteleri nükleer silah üretmenin hem İslam'a aykırı olduğunu hem de İran çıkarlarına zarar vereceğini belirtmelerine rağmen ${ }^{73}$ bu cevaplar verilmiştir. 2008 yılında aynı yöntemle yapılan bir diğer ankete göre katılımcıların \%58'i nükleer silah üretmenin İslam ilkelerine aykırı olduğunu belirtmişlerdir. ${ }^{74}$ İran' da 2013 yılında tesadüfi örnekleme yöntemiyle ve 1.000 katılımcı ile yapılan başka bir telefon anketine göreyse İranlıların \%63'ü İran'ın nükleer güç kapasitesinin artırılması gerektiğini düşünmektedirler. ${ }^{75}$

İran kamuoyunun fikirleri bu minvaldeyken 2008 y1lında, tesadüfi örnekleme yöntemiyle 1.003 örneklem ile ABD'de yapılan bir telefon anketine göre ${ }^{76}$ katılımcıların \%55'i İran'in barışçıl nükleer teknolojiye hakkı olduğunu, ${ }^{77} \% 65^{\prime}$ i diplomasi ile İran'ın nükleer silah geliştirmesinin caydırılabileceğini, sadece \%38'inin ise ekonomik yaptırımların caydırma unsuru olarak kullanılmaya devam etmesi gerektiğini düşünmektedirler. Amerikan dış politikasının şekillenmesinde kamuoyunun etkisi göz önüne alındığında bu sonuçlar, İran-ABD ilişkilerinin (ve dolayısıyla İran-Batı ilişkilerinin) sert güçten ziyade diplomasiyle şekillenmesi gerektiğine işaret etmektedir.

Tüm bu veriler izolasyon ve ambargo nedeniyle sıkıntılı bir durumda olan İran ekonomisine karşı beliren hoşnutsuzluğun İran'ın tüm halk kesimlerinde yaygın olduğunu ve barışçıl olmak kaydıyla nükleer enerjiye sahip olunmasından yana olunduğunu ortaya koymaktadır. İran Rejiminin önemli bir güvenlik açığını oluşturan neden, İran kamuoyunda Rejimin nükleer politikasını değiştirmek için oluşan muhalefet olsa da ${ }^{78}$ İran' da Rejimin meşruiyet ölçüsü nükleer program olarak görülmektedir. Zira özellikle ekonomik ve siyasi ambargolar neticesinde Rejimin temsilcilerine güvenin azalması, Kürt ve Beluç gibi bastırılmış etnik azınlıkların isyan temsilcileri olan Halkın Mücahitleri ve Cundullah Örgütleri bünyesinde Rejim karşıtı hareketlerin baş göstermesi ve 2009 Cumhurbaşkanlığ 1 seçimlerinde yaşanan Yeşil Hareket gibi örnekler Rejimin kendini sorgulamasında etkili olmuştur. ${ }^{79}$ Ayrıca İranlıların \%61'i dini esaslara göre seçilen ve halkın doğrudan oyuyla değiştirilemeyen Yüce Liderlik makamının da revize edilmesini düşünmektedirler. ${ }^{80} \mathrm{Bu}$ sorgulamalar neticesinde kendini dış politika konularında sert bir uluslararası aktör olarak kimlikleyen İran Rejimi, kamuoyunun ilgili konulardaki çabalarını -özellikle Yeşil Hareketten sonra- göz ard1 edememiştir. ${ }^{81} \mathrm{Bu}$ olgu sonucu radikal Ahmedinejad iktidarı, Hamaney ${ }^{82}$ izniyle, son bulmuş; kamuoyundaki

72 Sara Beth Elson ve Alireza Nader, What Do Iranians Think? A Survey of Attitudes on the United States, the Nuclear Program, and the Economy, California, RAND Institute, 2011.

73 Bunun sebebi 93. dipnotta, kaynağıyla birlikte kısaca izah edilmiştir.

74 World Public Opinion, "Poll of Iranians and Americans", 27 Ocak 2008, http://www.worldpublicopinion.org/pipa/ pdf/apr08/Iran_Apr08_quaire.pdf(Erişim Tarihi: 19 Mart 2016), s.13.

75 Mohamed Younis, "Iranians Feel Bite of Sanctions, Blame U.S., Not Own Leaders", 7 Şubat 2013, http://www.gallup. com/poll/160358/iranians-feel-bite-sanctions-blame-not-own-leaders.aspx (Erişim Tarihi: 19 Mart 2016).

76 Zogby International Research, American Perceptions of Iranian Americans Report, Aralık 2008, s.9. Bu oranlar aynı çalışmanın 2014 güncellenmiş versiyonunda da neredeyse aynı kalmıştır.

77 İran’ın barışçıl nükleer enerjiden taraf olması gerektiği ile ilgili ayrıntılı tartışmalar için bkz. Yost, "Analysing International Nuclear Order", 2007.

78 Herzog, Iranian Public Opinion, s.1.

79 Alireza Nader, Iran After the Bomb, Santa Monica, RAND Institute Press, 2013, s.8.

80 Terror Free Tomorrow Report, 2007.

81 Herzog, Iranian Public Opinion, s.14.

82 Hamaney’e göre İran'ın nükleer politikası ilerleme/gelişme ve halkın haklarının korunmasındaki kararlılık üzerine 
güçlenen muhalefete ve artan uluslararası baskılara karşı Rejim, pragmatik/yapıcı Ruhaniyi başa geçirmiştir. Böylece Ruhani ile başlayan yeni dönemde otokratik Rejim kendini sınırlayarak, hem halk temel hak ve özgürlükler ile refah noktalarında tatmin edilecek hem de uluslararası arenada meşruiyet artacaktır. Bu bağlamda İran Rejimi nükleer silahlı bir güç olup hem Batının ve hem de İran halkının tepkisini çekmek istememektedir. ${ }^{83}$ Zira Irak ile yapılmış sekiz yıllık savaşın ülkeyi ne kadar güçsüzleştirdiğini ve dünyadan kopardığını görmüş bir neslin varlığı, Hindistan-Pakistan nükleer rekabetinin iki ülke halkınca tepkiyle karşılanması ve Batı'dan daha da uzaklaşılması başta ekonomik olmak üzere İran'ı da yalnızlaştıracaktır. Bu bağlamda İran'ın yukarıdaki endişelerinin doğal bir sonucu olarak 2015 yılında P5+1 ile imzaladığı Kapsamlı Ortak Eylem Planı da bu çerçevede değerlendirilmelidir.

\section{Veri-Yöntem}

Araştırmanın evreni, İran'ın başkenti ve en kalabalık şehri olan Tahran'daki 10 devlet üniversitesi özelinde, ${ }^{84}$ öğretim üyeleri $(\% 26)$ ile doktora $(\% 50)$ ve yüksek lisans $(\% 24)$ öğrencileri olup bu evren, veri temizliğinden sonra kalan 603 kişilik örneklem üzerinden analiz edilmiştir. Örneklemin yüksek lisans ve üstü katılımcılardan oluşmasının sebebi, eğitim seviyesi artan bireyin İran resmiyle ilgili daha objektif ve net görüşlere sahip olacağ1 varsayımından kaynaklanmaktadır. Özellikle İran'ın iç ve dış politikası ile ilgili, entelektüel birikim gerektiren anket sorularına en net cevabın verilebilmesi için bu örneklem seçilmiş ve lisans öğrencileri örnekleme dâhil edilmemiştir. Bu bağlamda örneklemin temsil kabiliyeti noktasında İran halkından kasıt, dış politikayı takip eden/edebilenlerdir. Dış politika analizinde gerekli olan uzmanlığın bu örneklemde mevcut olduğu kabul edilmiştir. Anketin dili Farsçadır. Şubat-Nisan 2013 tarihleri arasında ${ }^{85}$ yapılan çalışmanın örneklem seçim metodu, tesadüfi örnekleme yöntemlerinden çok aşamalı örnekleme yöntemidir. ${ }^{86}$

İran kamuoyunun dış politikayı sınırlandırma yetisi; kamuoyunun tehdit algılamaları, nükleer programa ve diş politik aktörlere bakışı çerçevesinde ölçülmüştür. Çalışmada diş politik aktörlere güven sorusunda Omnibus Ölçeği (0-10 puan arasında ölçeklendirilmiştir) diğer ifadelerdeyse kapalı uçlu sorularla ölçeklendirme yapılmıştır. Ankette kullanılan soru ifadeleri ilgili tablolarda ayrı başlıklar altında verilmiştir.

Çalışmanın geçerliliği çerçevesinde en genel ama en önemli bulgu, birbirinden bağımsız katılımcıların ilgili düşüncelerinin farklı yer ve zamanda ayrı ayrı ölçülmesiyle kişisel algı ve bilgiden üstün, daha isabetli verilere ulaşılarak kitlelerin bilgeliğinin ortaya

temellendirilmiştir; fakat liderliği Rehber yapacaktır. Ali Hamaney, "Ayatollah Khamenei speaking to Iranian officials", 10 Ekim 2006, www.leader.ir/langs/FA/index.php?p=bayan\&id=3295 (Erişim Tarihi: 19 Mart 2016).

83 Karim Sadjadpour, “On Iranian Public Support for Tehran’s Nuclear Ambitions”, 13 Mart 2006, http://www.cfr.org/ $\mathrm{iran} /$ sadjadpour-iranian-public-support-tehrans-nuclear-ambitions/p10100 (Erişim Tarihi: 19 Mart 2016).

84 Örneklemin demografik özellikleri Tablo 1'deki gibi olup istatistiki olarak homojen bir örneklemin sağlanması amacıyla başkent Tahran'daki tüm üniversitelerde ilgili anket çalışması yapılmıştır. Üniversiteler ve analize tabi katılımcı sayıları şöyledir: Tahran Üniversitesi (189), Azad Üniversiteleri (138), Tabatabai (48), Ez-Zehra (45), Şehid Beheştî (42), Emir Kebir (38), Ulum ve Tahkikat (33), İmam Sadık (30), Peyam-i Nur (21), Tarbiat-e Mo'alem (19).

85 Bu tarihlerde yapılan çalışmadaki veriler günümüzde de önemlidir. Zira yüksek bir eğitim seviyesine ve dolayısıyla sağduyuya sahip örneklemin dış politika gibi uzmanlık ve birikim gerektiren konulardaki düşünceleri günümüzde de geçerliliğini korumaktadır. Ayrıntılı bilgi için bkz. Michael Woodley, Are high-IQ individuals deficient in common sense?, 2010; Heiner Rindermann et.al., Political Orientations, 2012.

$86 \mathrm{Bu}$ yöntem ile örnekleme kümeleri belirlendikten sonra bu kümeler arasından rastgele örnekleme yöntemi ile katılımcıların (yaş, gelir, dindarlık gibi) kotaları göz önünde bulundurularak anket uygulanmıştır. 
çıkarılmış olmasıdır. ${ }^{87}$ Bununla birlikte çalışmada yüzeysel/genel ve içerik geçerlilik analizleri de yerine getirilmiştir. Çalışmanın amaç ve sınırlılıkları kapsamında incelenecek konu, boyut ve ölçekler yüzeysel geçerlilik yöntemi ile Türkçe ve İngilizce ilgili literatür tarandıktan sonra tespit edilmiş; içerik geçerliliğinde ise Türk ve İranlı akademisyen ve uzmanların ${ }^{88}$ görüşlerine başvurularak içeriğin, araştırma konu ve amacını kapsadığına kanaat getirilmiştir. Konu ile ilgili daha önceden yapılmış benzer çalışmalar literatür bölümünde ifade edilmiş ve çalışmanın Yapısal Geçerliliği sağlanmıştır. Buna karşın konu ile ilgili ulaşılmak istenen hedef bağlamında çok soyut bir yöntem olduğu için Kriter Geçerlilik Yöntemi uygulanmamıştır.

Veri setinden hareketle ve çalışmanın örneklemi bağlamında tüm İran kamuoyunun genel bir resmini çıkarmak amacıyla ilgili analizlerin her biri sosyodemografik bağımsız değişkenler alt başlıklarında ele alınmamıştır. Buna karşın en temel iki analizde (İran’ın nükleer silah programına karşı olanlar ile İran'ın nükleer programına bakışı sosyodemografik karşılaştırmaları) yaş, gelir ve dindarlık bağımsız değişkenlerince verilen cevaplar incelenmiş ve toplumsal katmanlar arasındaki görüş farklılıkları ortaya konulmaya çalışılmıştır. ${ }^{89}$ Çalışmayla ilgili temel sosyodemografik istatistikler aşağıdaki tablodaki gibi olup analizler, ankete katılan katılımcılar üzerinden gerçekleştirilmiş, geri kalanlar ise "Fikrim Yok" veya "Cevap Vermeyenler" olarak analiz dişı tutulmuştur.

Tablo 1: Çalışmadaki Sosyodemografik Katmanlar

\begin{tabular}{|c|c|c|c|}
\hline & & Sıklık & Geçerli Yüzde \\
\hline \multirow{2}{*}{ Mezhep } & Şii & 548 & 93,4 \\
\hline & Sünni & 39 & 6,6 \\
\hline \multirow{7}{*}{ Etnik Köken } & Farsi & 129 & 21,7 \\
\hline & Azeri & 51 & 8,6 \\
\hline & Kürt & 36 & 6,1 \\
\hline & Türk & 130 & 21,8 \\
\hline & Arap & 30 & 5 \\
\hline & Lur & 29 & 4,9 \\
\hline & Aria/Aryan & 190 & 31,9 \\
\hline \multirow{3}{*}{ Kişisel Dindarlık } & Az Dindar & 290 & 48,9 \\
\hline & Orta Dindar & 200 & 33,7 \\
\hline & Çok Dindar & 103 & 17,4 \\
\hline \multirow{3}{*}{ Aylık Gelir } & Alt Gelir Grubu & 137 & 33,7 \\
\hline & Orta Gelir Grubu & 176 & 43,3 \\
\hline & Üst Gelir Grubu & 93 & 22,9 \\
\hline \multirow{2}{*}{ Yaş } & 27'den Küçük & 298 & 49,4 \\
\hline & 27 ve Üstü & 305 & 50,6 \\
\hline
\end{tabular}

87 Ayrıntılı bilgi için bkz. James Surowiecki, The Wisdom of Crowds, New York, Anchor Books, 2005, s.3-22.

88 İranlı akademisyenler Tahran Üniversitesi’nde konu üzerinde uzman öğretim üyelerinden oluşmaktadır. Alan çalışması da bu akademisyenler tarafından yapılmıştır. Türk akademisyenlerse ülkemizdeki araştırma merkezleri ve üniversitelerde görevli, İran üzerine çalışmaları olan öğretim üyesi ve uzmanlardan müteşekkildir.

89 Yüksek yaş, gelir ve dindarlığa sahip, Rejimin temel taşıyıcısı olan bu grup orta yaş ve üstü, dini ve siyasi elitlerden meydana gelmektedir. Bu bağlamda İran özelinde siyasi ve dini elitizmle ilgili ayrıntılı bilgi için bkz. Eva Patricia Rakel, The Political Elite in the Islamic Republic of Iran, 2009, s.105-125. 
Tablodan hareketle, örneklemin \%93,4'ünün Şiilerden ve \%6,6'sının Sünnilerden elde edildiği görülecek olup bu oran İran'daki mevcut mezhepsel orana da çok yakın bir değerdir.

Katılımcıların sübjektif tercihleri ile şekillenen Kişisel Dindarlık değişkeni (Omnibus Ölçeği ile 0-10 puan arasında ölçeklendirilmiştir) yeniden kodlanarak 0-4 puan arası $A z$ (290 katılımc1/\%48,9), 5 puan Orta (200 katılımc1/\%33,7) ve 6-10 puan arası Çok Dindar $(103$ katılımcı/\%17,4) olarak kodlanmıştır. Orta dindarların sadece 5 puan olarak seçilmesi, katılımcıların bu puanda öbekleşmelerinden kaynaklanmaktadır. İran gibi dindarlığın devlet yürütme organlarıyla kontrol edildiği bir ülkede (Omnibus kullanılsa bile) ankete katılanların ifadelerini tek veri olarak ele almanın eksik olacağından hareketle katılımcıların cevapları anketin içindeki kontrol sorularıyla teyit edilmiştir. Çalışmada kendisini çok dindar olarak ifade edenlerin oranı \%17,4'tür. Ayrıca bu grup Rejimin de temel taşıyıcısıdır. Bununla birlikte çalışmada Rejimi destekleyen önermelere katılım da benzer oranlarda çıkmıştır: "İran'da seçilmiş yöneticilerin icraatları hakkında kamuoyu yeterli bilgiye sahiptir” \%21,5; “İran'da insanlar oylarını bask1 altında kalmadan özgürce kullanabilmektedir” \%15,2; “İran' da Demokrasinin işleyişinden memnunum” \%11,8; “İran’ da seçilmiş yöneticiler halkın taleplerine karşı duyarlıdır" \%16,2; "İslami rejim, demokrasi ve dış politika alanlarında yeterli cevap vermektedir” \%14,3; "Gazeteciler, yazarlar vs. medyada fikirlerini özgürce ifade edebiliyorlar” önermesine katılanlarsa \%12,5 oranlarındadır. Ayrıca İran'da 0-10 arasındaki memnuniyet ölçeğinde 6-10 arasında (yüksek) memnun olanların oranları şunlardır: Yaşam kalitesi \%16,3; can güvenliği \%22,8; farkl1 kimliklere sayg1 \%17,5; fikir özgürlüğü \%11; insan hakları ve demokrasi \%11,5'tir. Güven ölçeğinde ise Hizbullah'a güven \% 15'tir. Son olarak Türkiye'ye bakışta; Türkiye Ortadoğu ülkeleri için laik siyasi yapısı nedeniyle model olamaz diyenler \%16,9; yeterince Müslüman olmadığ 1 için model olamaz diyenler \%12,9 oranlarında çıkarak çok dindarlarla benzer algılamalara sahip oldukları kontrol edilmiştir. Bu algılamalar geliri yüksek katılımcılar için de benzerdir.

Bu bağlamda gelir değişkeni, dindarlık değişkenindeki yöntem takip edilerek hazırlanmıştır. Buna göre 200.000-800.000 Tuman ${ }^{90}$ arası geliri olanlar Alt Gelir Grubu, 800.001-1.600.000 Tuman arası Orta Gelir Grubu ve bundan daha fazla geliri olanlar Üst Gelir Grubu olarak kodlanmıştır. ${ }^{91}$

Yaş değişkeninde 27 yaşından küçük olanlar ile 27 ve daha büyük yaşta olanlar olmak üzere iki gruplama yapılmıştır. En küçük yaşın 21 en büyük yaşın ise 69 olduğu çalışmada ortanca yaş olarak tespit edilmiş olan 27 yaşından küçükler, örneklemin \%49,4'ünü oluştururken yaşı 27 ve daha büyük olanlar ise örneklemin \%50,6'sını teşkil etmiştir.

90 Ocak 2016 tarihi itibariyle 1 Tuman=10 İran Riyali=0,001 Türk Lirasıdır.

91 Çalışmamızda üst gelir grubuna dâhil katılımcı oranı \% 22,9'dur. Bununla birlikte İran'da asgari ücret aylık 120\$, mühendis aylığı ise 500-600\$ seviyelerindedir. İran'da Türkiye’ye göre yaşam daha ucuz olsa da kümülatif gelir azdır. Bu bağlamda benzinin litresi 10 cent (fakat karne ile satılır), yerli binek araç $6000 \$$, uçak ile en uzak yere gidiş geliş $50 \$$, 5 yıldızlı otelde konaklama 100-120\$, bir litre süt 50 cent, bir kilo et 4,5\$, bir kilo peynir 3\$, Tahran'da en uzak yere taksi ücreti ise 3 dolardır. Ayrıca İran'ın kişi başına GSYH 5.200\$, işsizlik \%14, enflasyonsa \%15 civarındadır. Ayrıntılı bilgi için bkz. http://www.mfa.gov.tr/iran-ekonomisi.tr.mfa; https://www.cia.gov/library/publications/the-worldfactbook/geos/ir.html. 


\section{Bulgu ve Yorumlar}

Bu bölümde İran reelpolitiğinin en önemli çıktıları olan dış tehdit, nükleer güç ve nükleer silah programları ile dış politik aktörlere güven algılamaları ölçülerek Rejim ile halk arasında ilgili algılara bakışta fark olup olmadığı sorgulanacaktır. Bu sorgulamada literatür bölümünde açıklanan reelpolitik ve kamuoyu tartışmaları esas alınacaktır.

\section{İan Kamuoyunun Dış Tehdit Algılaması}

İran'ın dış tehditlere cevap verme pratiğinin ne olması gerektiğini ölçmek maksadıyla katılımcılardan İran'1n diş tehditlere cevap verirken kullanılması gereken ilk üç yöntemi seçmeleri istenmiştir. Soru ve önermelere verilen geçerli cevapların kümülatif frekans dağılımı aşağıdaki gibidir.

Tablo 2: İran Olası Dış Tehditlere Nasıl Karşılık Vermeli? (\%)

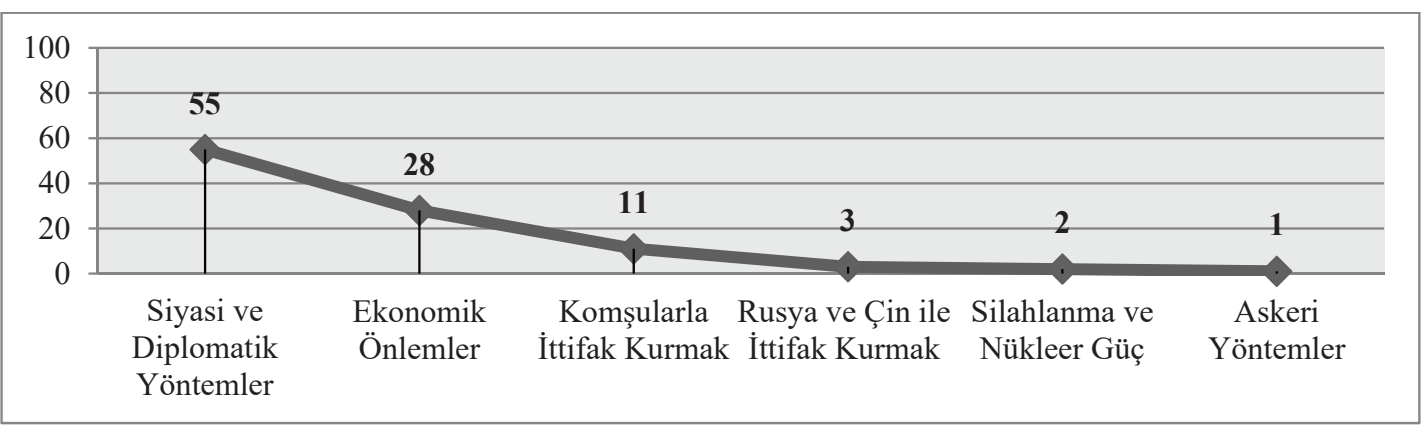

Buna göre İran kamuoyu, uluslararası ilişkiler ve güvenlik ile ilgili konularda sert güçten ve dolayısıyla reelpolitikten değil siyasi ilişkilerin güçlendirilmesini hedefleyen idealpolitik hedefli yumuşak güçten taraftır. ${ }^{92}$ Örneklemin yarıdan fazlası dış tehditlere karşı siyasi ve diplomatik yöntemlerin kullanılması gerektiğini düşünürken Rusya ve Çin dâhil ortak bir askeri karşılık verme isteği sadece \%6 seviyelerindedir. Dolayısıyla katılımcıların çok yüksek bir ekseriyeti askeri değil siyasi, diplomatik veya ekonomik yollarla sorunların çözülmesinden yana iradelerini ortaya koymuşlardır. Askeri ve sivil çözüm yolları arasındaki bu derece büyük bir farktan dolayı İran kamuoyu, Rejimin dehşet dengesi çerçevesinde uluslararası arenada hak arayışına karşı çıkmaktadır.

\section{İan Kamuoyunun Nükleer Silah Programına Katılımı}

İran kamuoyunun hangi gerekçelerle nükleer silah programına karşı olumlu tavır geliştirdiğini ve nükleer silah programına bakışının yönünü tespit etmek maksadıyla çalışmadaki soru ve önermelere verilen geçerli cevapların frekans dağılımları aşağıdaki gibidir.

92 Sert ve yumuşak güç ilişkileri için bkz. Ernest Wilson, "Hard Power, Soft Power, Smart Power", The Annals of the American Academy of Political and Social Science, Cilt 616, No 1, 2008, s.110-124. 
Tablo 3: İran Nükleer Silah Programına Hangi Amaç İçin Katıliyorsunuz? (\%)

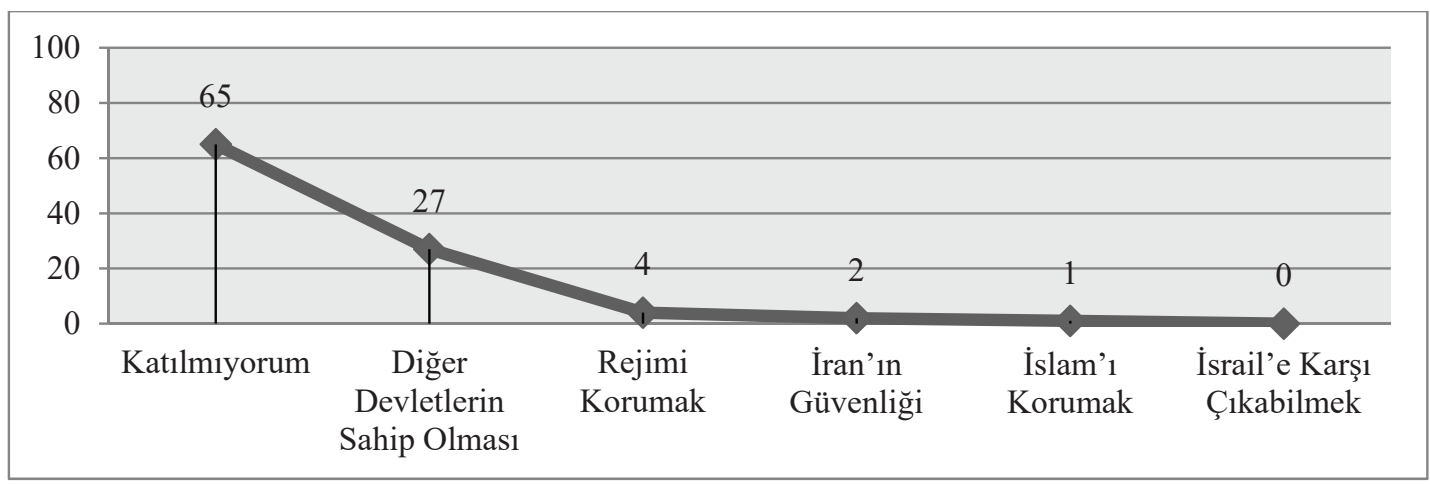

Buna göre alınan cevaplar İran halkının nükleer silaha destek verdiği önyargılarını tamamen yanlışlar mahiyettedir. Zira katılımcıların \%65'i hangi sebeple olursa İran'ın nükleer silah geliştirme çabalarına devam etmemesi gerektiğini düşünmektedir. $\mathrm{Bu}$ oran gerek ulusal gerekse uluslararası aktörlerin göz ardı edemeyeceği kadar önemli bir gerçekliktir. Katılımcılardan \%27'lik bir kesim ise uluslararası sistemde kabul görmüş nükleer ülkeler gibi egemen ve bağımsız bir ülke olan İran'ın da bu "hakka" sahip olması gerektiğini düşünmektedir. Bir önceki tablodakiyle eşit oranda ve o görüşü teyit edici mahiyette, katılımcıların sadece \%6'sı ülkenin, Rejimin ve dinin korunması için nükleer silahın bir gereklilik olduğu görüşündedirler. ${ }^{93}$ Bununla birlikte çalışmamızda da geçen Terror Free Tomorrow'un yaptığı çalışmaya göre de katılımcıların \%33'ü nükleer silah geliştirilmesini isterken bizim çalışmamızda da bu oran \%34 olarak çıkmış ve çalışmanın geçerliliğini artıran bir unsur olmuştur.

\section{Iran Kamuoyunda Nükleer Silah Programına Karşı Olanların Sosyodemografik Özellikleri}

Bir önceki soruda ezici bir şekilde İran'ın nükleer silah programına karşı olanlar, farklı bağımsız değişkenlerce derinlemesine analiz yöntemleri kullanılarak bu başlık altında incelenmiştir.

$93 \mathrm{Bu}$ bölümdeki değerler arasındaki derin farkın sebeplerinden birisinin Rehber tarafından nükleer silahların kullanılmasının haram olduğu fetvası olduğu öngörülmektedir. Zira İran-Irak savaşında Saddam Hüseyin, kimyasal silah kullanarak 20 bin İranlıyı öldürmüş ve 100 binini yaralamış olmasına ve hatta İran Devrim Muhafızları Ordusu'nun da nükleer, biyolojik ve kimyasal silahların kullanılmasından yana olmasına rağmen Humeyni, bu silahların kullanılmasının haram olduğunu, sadece savunma maksatlı önlemler alınması gerektiğini tebliğ etmiştir. Ayrıntılı bilgi için bkz. Gareth Porter, "When the Ayatollah Said No to Nukes", 16 Ekim 2014, http://foreignpolicy.com/2014/10/16/when-theayatollah-said-no-to-nukes/ (Erişim Tarihi: 19 Mart 2016). 
Tablo 4: Nükleer Silah Programına Karşı Olanların Sosyodemografik Özellikleri

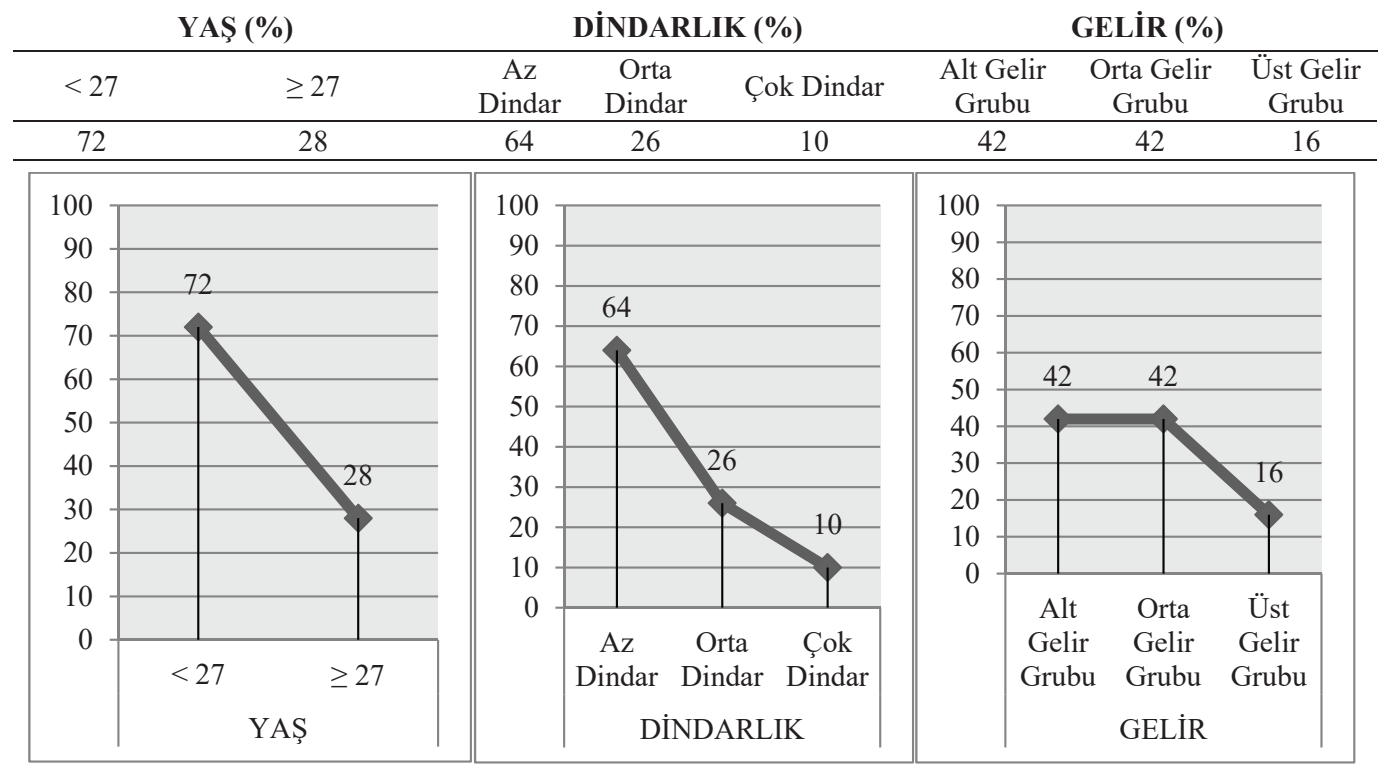

Buna göre İran'da gençlerin (yaşı 27'den küçük olanların) \%72'si İran'ın nükleer silah programına karşıdırlar. Yaş ilerledikçe nükleer silaha karşı olma oranı düşmektedir. Bunun nedenini, yaşı ileri olan kişilerin İran-Irak savaşını bizzat yaşamış olmaları örneği sonucu ileride yine böylesi bir senaryo karşısında kendilerini koruma refleksi olarak yorumlamak mümkündür. Ayrıca hem Devrim'i hem de Savaş'1 yaşamamış ve İran nüfusunun çoğunluğunu oluşturan yeni neslin daha barışçıl olarak dünyaya yaklaştığını da kabul etmek gerekir. ${ }^{94}$ Bununla birlikte katılımcıların bireysel dindarlık düzeyleri arttığında nükleer silaha karşı olma oranı da yüksek oranda azalmaktadır. ${ }^{95} \mathrm{Bu}$ bulgudan elde edilecek en basit ve en önemli sonuç Anayasada dahi (örneğin 19. ve 115. maddeler) dindar olması önem arz eden bir halk üzerine kurulması gereken İran Rejiminin temel destekçisi olan dindarların hala yüksek oranda Rejimi nükleer konuda da desteklediğidir. Bununla birlikte İran'da bürokrasinin dindarlar üzerine şekillendiğinden hareketle, kamuoyunun İran'1 nükleer olarak sınırlamasının sınırı da çizilmektedir. Zira Rejim ancak uygun gördüğü ve başka bir yol kalmadığı takdirde (reelpolitiğe uygun olarak) kendini sinırlayabilecektir. Dindarlık verisine benzer şekilde katılımcıların gelir seviyeleri göz önüne alındığında ise az ve orta gelire sahip \%84'lük bir kesim nükleer silaha karşıyken üst gelir grubundaki katılımcıların sadece \%16'sı nükleer silah karşıtıdırlar. İran özelinde bürokratik elitizm olarak ifade edilebilecek; hem dindar hem de yüksek gelirli kesimlerin Rejimi yüksek oranda desteklemesi, Rejimden elde edecekleri rant ve ekonomik faktörlerin, her ne şekilde olursa olsun, denetlenebilirliğine karşı statükonun devamından yana bir duruş olarak yorumlanmalıdır.

94 Akbarzadeh, Democracy, s.477.

95 93. dipnotta açıklandığı üzere Humeyni’nin nükleer silah üretimi ve kullanımını yasaklamasına rağmen çok dindarların nükleer silah sempatisi bu grubun uluslararası izolasyon, Batı karşıtlığı ve dinin korunması sebepleriyle nükleer silahı günümüzde bir gereklilik olarak gördüklerini ortaya koymaktadır. 


\section{Iran Kamuoyunun Nükleer Programa Bakışı}

İran kamuoyunun büyük çoğunluğunun nükleer silah programına karşı olduğu bir önceki tabloda bulgulanmıştır. Bu başlık altında ise kamuoyunun genel olarak nükleer programdan beklentileri analiz edilecektir. Böylece nükleer silaha karşı olan kamuoyunun nükleer programa da karşı olup olmadığı bulgulanacaktır.

Tablo 5: İran Kamuoyunun Nükleer Programa Bakış1

\section{Cevap Seçenekleri}

Katılıyorum Katılmıyorum Kisaltma

Ortadoğu nükleer silahlardan arındırlmalı ve tüm ülkelerle birlikte Iran da nükleer silah üretmeme taahhüdü vermelidir.

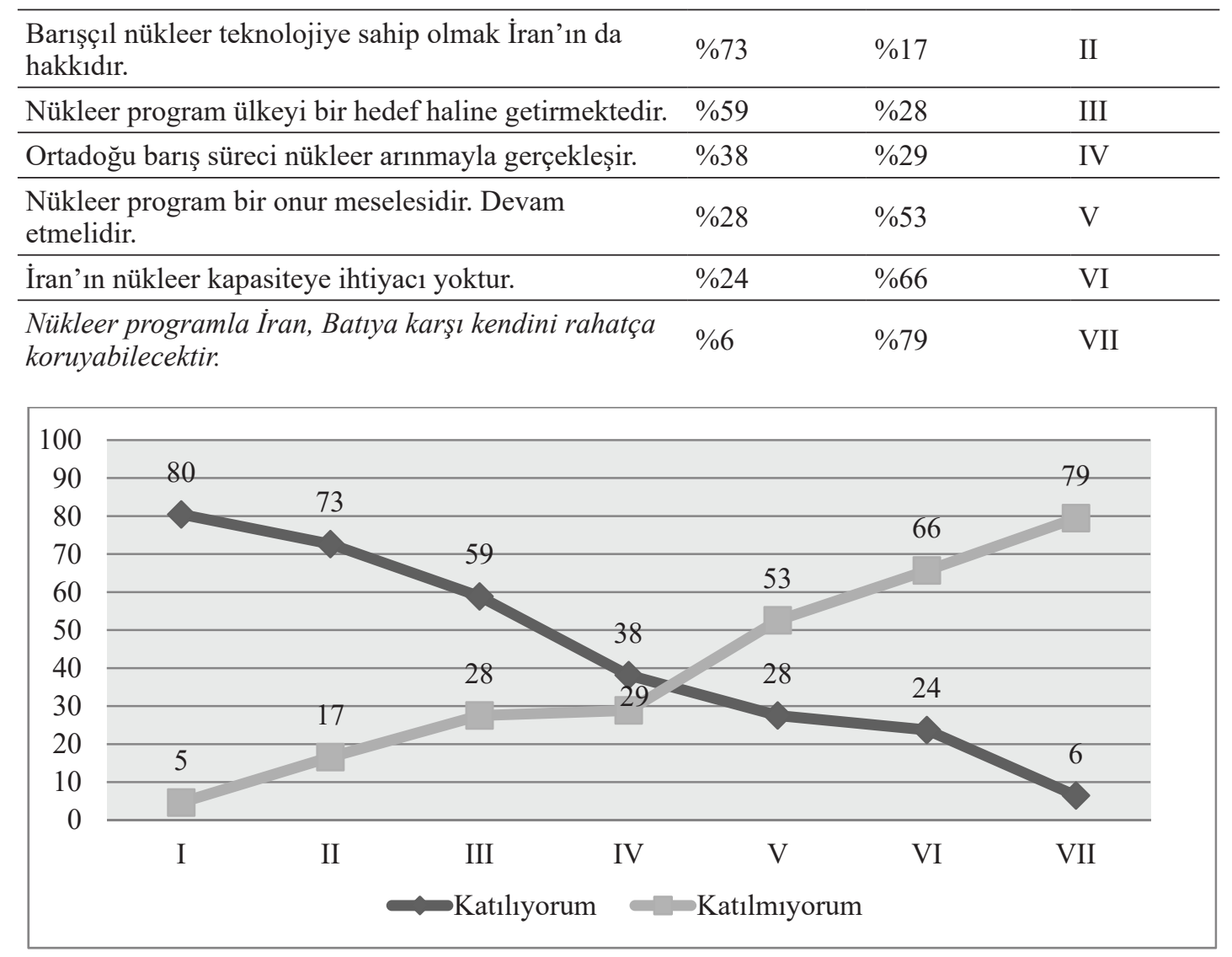

$\mathrm{Bu}$ verilerden hareketle diyagramda da net olarak görüleceği üzere İran kamuoyu Ortadoğu'nun nükleer olarak silahsızlandırılması gerekse de barışç1l amaçlarla nükleer gücün kullanılması gerektiğini ve nükleer programın İran’ı bir hedef haline getirdiğini düşünmektedir. Buna karşın İran kamuoyu nükleer program devam etse ve başarılı olsa dahi İran'ın Batıya karşı kendini koruyamayacağını, İran'ın nükleer güce ihtiyacı olmadığını, bunun bir onur meselesi olarak algılanmaması gerektiğini düşünmektedir. 


\section{Iran Kamuoyunda Nükleer Programa Bakışın Sosyodemografik Karşılaştırması}

İran kamuoyunun nükleer programa bakışı tablosunda ilgili önermelere en çok ve en az katılanların sosyodemografik özellikleri aşağıdaki gibidir.

Tablo 6: Nükleer Programa En Çok Katılanların Sosyodemografik Özellikleri

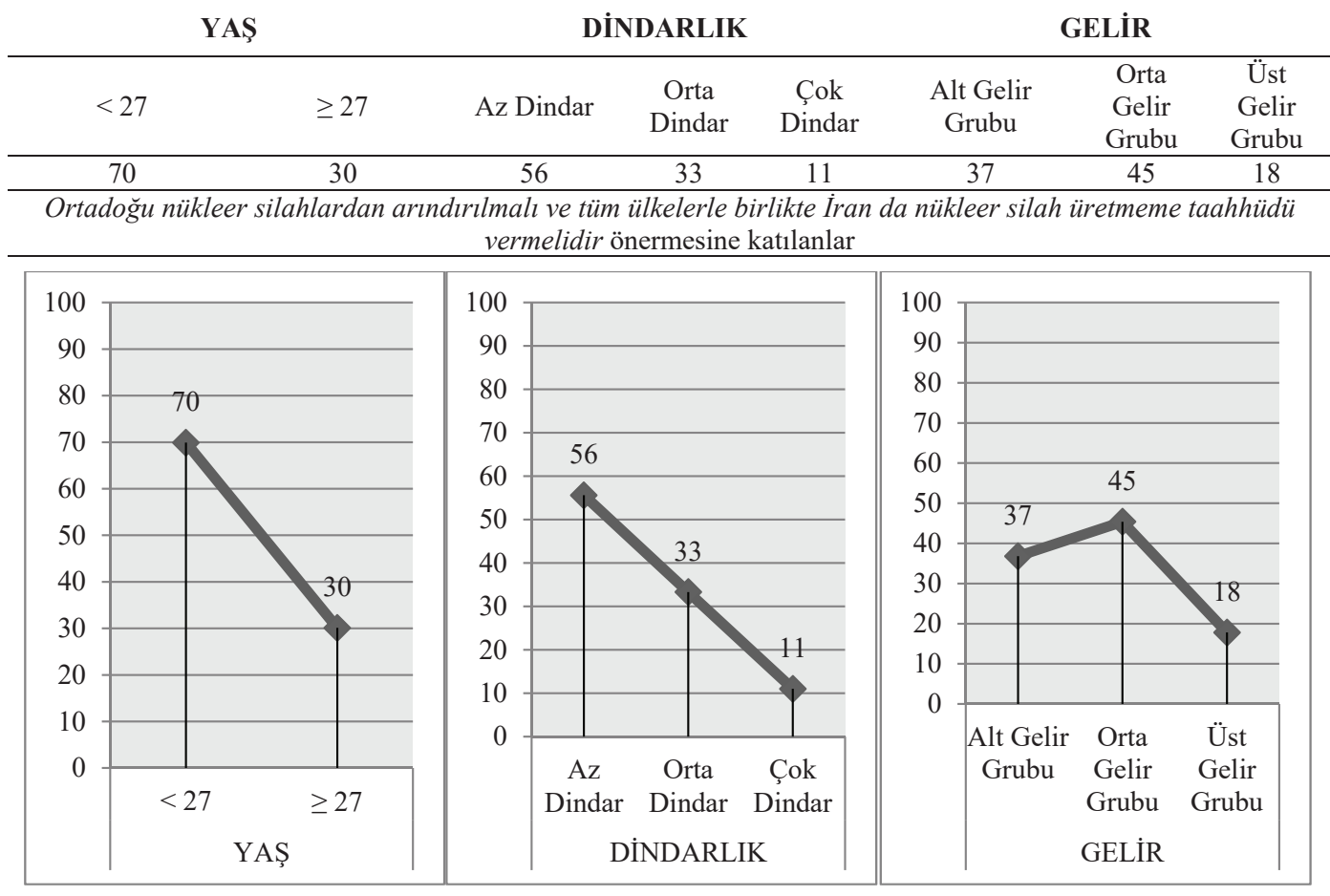

Buna göre "Iran'ın nükleer silah programına karşııı"” diyenlerin sosyodemografik özelliklerindekine çok yakın oranlarda cevaplar alınmıştır. İran’da gençlerin \%70’i, az ve orta dindarların ${ }^{96} \% 89$ 'u, alt-orta gelirli katılımcıların \%82'si İran dâhil tüm Ortadoğu coğrafyasının nükleer silahlardan arındırılması gerektiğini düşünmektedir. Buna karşın artan yaş, dindarlık ve gelir seviyesi ile nükleer silahlara "sempati” de artmaktadır. Rejimin hem iç hem de dış politikasının reelpolitik/teopolitik eksende devamından yana olan bu gruba rağmen tek avantajı sayıca üstünlük olan İran kamuoyunca Rejimin reelpolitik ekseni sinırlandırılmaktadır.

96 Veri setimizde 0 ile 5 puan arası az ve orta dindar olarak kodlanmış, 6 ve yukarısı ise çok dindar olarak kodlanmıştır. Dolayısıyla çok dindarların ilgili oranları daha geniş aralıklı olduğu için oranların kısılması halinde (örneğin 8-10 arası çok dindar olarak tanımlandığı zaman) daha keskin sonuçların çıkacağı göz ardı edilmemelidir. 


\section{Iran Kamuoyunun Dış Politik Aktörlere Güven Algısı}

Aşağıdaki analizde İran kamuoyunun dış politikada en çok ve en az güvendiği uluslararası aktörler gösterilmektedir. Katılımcıların güven skalasına göre \%55 ile Japonya en güvenilen ülke olurken \%20 ile Suriye, İran kamuoyunca en az güvenilen ülkedir.

Tablo 7: İran Kamuoyunun Diş Politik Aktörlere Güveni (\%) ${ }^{97}$

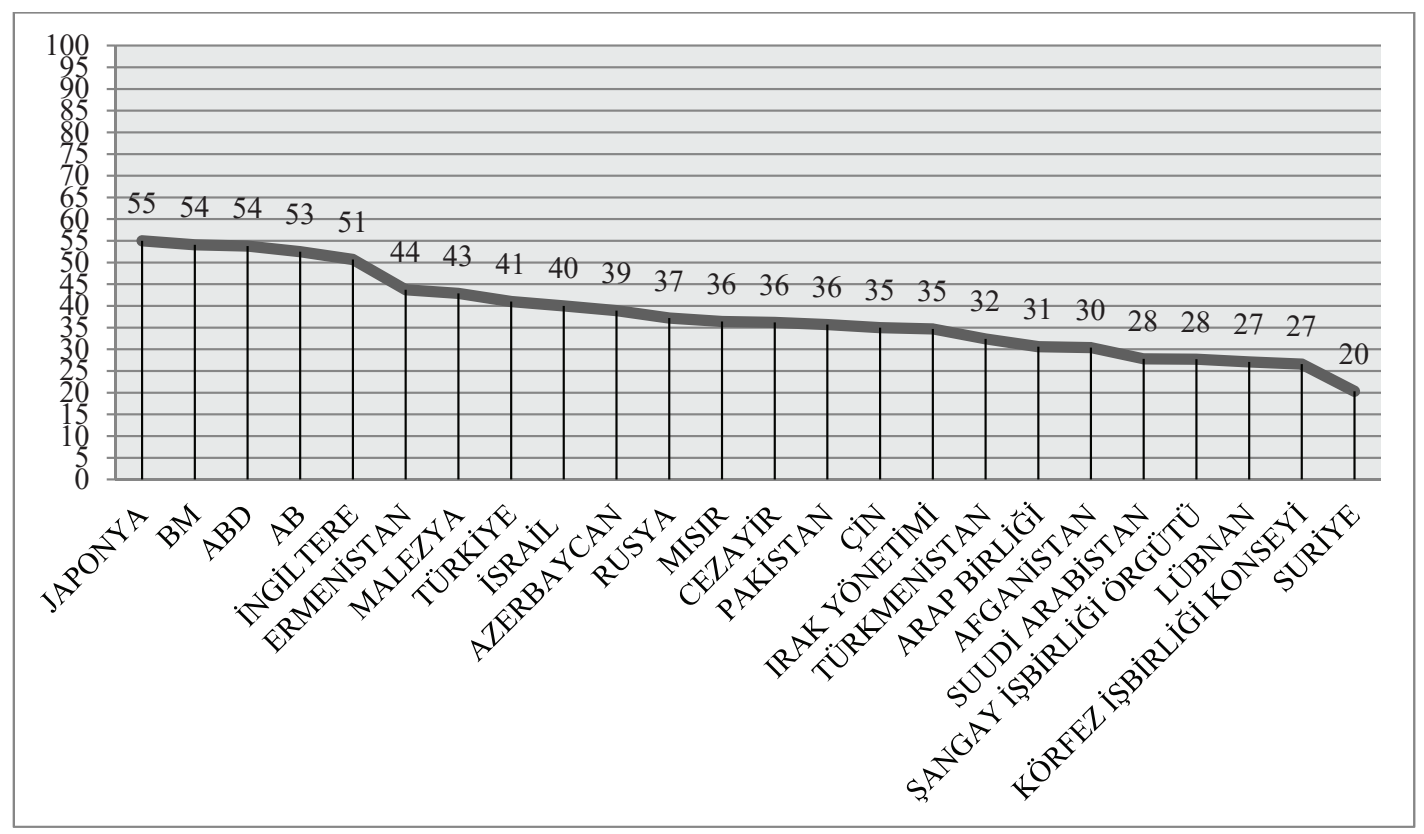

Tablodan hareketle İran kamuoyunun hiçbir uluslararası örgüt veya devlete ortalamanın üstünde güvenmediği ortaya çıkmaktadır. Bu bağlamda İran kamuoyunda farklı uluslararası aktörlere ilişkin yerleşik olan algı güvensizliktir. Evrenimizdeki ilgili aktörlere güven duymak ise istisnai bir durumdur. Doğal olarak bu betimlemeyi, ülke içinde yaşanan algısal durumun bir yansıması olarak yorumlamak mümkündür. Kişilerin ülke içinde diğer kişi ve gruplara karşı yaşadığı güvensizlik duygusu aynı zamanda kendisini uluslararası aktörlere karşı da benzer şekilde göstermektedir. Bu bağlamda özellikle Japonya, BM, ABD ve AB gibi Batı kavramının içini dolduran aktörlere güven ortalamanın biraz üstündeyken diğer komşu ve Müslüman ülkelere güven çok daha azdır. Bununla birlikte İran kamuoyu Türkiye ve İsrail’e aynı oranlarda güvenmektedir. Özellikle İsrail’e güvenin bu kadar yüksek olmasında Batıca

97 Seçilen ülkeler, İran’a karşıtlık esası üzerine belirlenmiştir. Bu bağlamda çalışmaya -Avrupa özelinde- İngiltere dâhil edilmişken Almanya ve Fransa, AB çatısı altında dâhil edilmiştir. Zira İngiltere 1856'da Herat Meselesi, 1946'da İran'ın İngiltere ve Rusya tarafından işgali, 1953'te petrolün millileştirilmesine karşı “Ajax Operasyonu” darbesi, 2007'de Salman Rüşdi'ye İngiltere tarafından şövalye nişanı verilmesi, 2009'da Hamaney’in İngiltere'yi düşmanların içinde en şeytani olarak tanımlaması gibi nedenlerle İran için İngiltere Avrupa'daki en önemli ötekidir. Buna karşın 1871'de Almanlarla resmi ilişkilerin başlaması, İran'ın özellikle Rıza Şah’tan itibaren, Almanya hayranı yöneticilerce yönetilmesi, Nazi döneminde büyük ekonomik işbirliklerinin yaşanması ve iki ülkenin de aryan unsurunu esas alan tarihten gelmeleri gibi nedenlerle özellikle Almanya' yla İran arasında bir ittifak tarihi mevcuttur. Asya özelinde ise İran'ın Tacikistan'ı “iki canda bir ruh olarak” tanımlaması, Tacikçenin Farsçanın bir lehçesi olması, Hindistan’ın İran için çok önemli bir ekonomik müttefik olarak görülmesi nedenleriyle bu ülkeler de çalışmaya dâhil edilmemiştir. 
uygulanan ambargo ve yaptırımların etkisinin yanında her kim olursa olsun Batıyla anlaşılması gerektiğinin bir göstergesi olarak yorumlanmaktadır. Veriyi önemli k1lan diğer bir detay ise Şii Hilali kapsamında İran Rejiminin açıktan destek verdiği Suriye ve Lübnan gibi rejimlere İran kamuoyunun en az güvendiği gerçeğidir. Bu verilerden hareketle İran kamuoyunun, Batıyla bütünleşmiş ama egemenlik ve bağımsızlığını da kaybetmemiş bir ülke olmak istediği sonucuna ulaşılmıştır.

\section{Sonuç}

Ülkelerin en sert reelpolitiği, askeri ve politik güce/çıkara dayalı statükonun devamı olsa da her ülkenin kamuoyu, o ülkenin dış politika retorik ve pratiklerini yüksek oranda etkilemektedir. $\mathrm{Bu}$ bağlamda İran Devletinin reelpolitik dış politika pratiği de daha fazla temel hak ve özgürlükten yana İran kamuoyu tarafından sınırlandırılmış ve böylece uluslararası arenada bir dehşet dengesinin yaşanmasının önüne geçilmiştir.

Çalışmanın verilerinden de bulgulandığı üzere İran Rejiminin dış politik çıkarları iç kamuoyu ile çatışmaktadır. Zira kamuoyu her şeye rağmen Batıya daha çok, Doğuya daha az güvenmekte, olası tehditlere karşı yumuşak güç eksenli siyasetle karş111k verilmesinden yana, nükleer potansiyeli barışçıl amaçlar için kullanmaktan taraf ve nükleer silah üretimine karşıdır. Rejimi temsil eden yüksek yaş, yüksek gelir ve yüksek dindarlık seviyesindeki muktedir azınlık elitlerin etkisine rağmen günümüzde Rejim, dış politikasını mutlak reelpolitik merkezli değil, ABD örneğindeki gibi, iç kamuoyu baskısını da dikkate almak "zorunda kalarak" dış politikayı yürütme anlayışındadır. Bununla birlikte İran’da yönetimin dindarlar üzerine şekillendiği düşünüldüğünde kamuoyunun, Rejimi nükleer konuda sınırlamasının sınırı da çizilmektedir. Zira Rejim/Rehber ancak uygun gördüğ̈̈ ve başka bir yol kalmadığı takdirde kendini sinırlayabilecektir.

Bu bağlamda Rejimin kendini sınırlamas1; P5+1 ülkeleri ile müzakerelerin olumlu sonuçlanması ve İran'ın dünya siyasetine yeniden entegre olması neticesinde hem uluslararası sistemde İran'in kabulüne ve izolasyonun sona erdirilmesine hem de -Yeşil Hareket'te de izleri görüldüğü üzere-iç politikada farklı etnik, dini ve siyasi grupların temel hak ve özgürlüklerinin artmasına sebep olabilecektir. Buna rağmen İran siyasetinde siyasal parti sisteminin olmamas1, kamuoyunu temsil edecek hükümet dışı organizasyonların zayıflığı ve Rejimin halk üzerindeki baskın karakteri İran kamuoyunun önemli bir çıkmazı durumundadır. Ayrıca Rejimin, özellikle Humeyni'nin fetvasına rağmen neden nükleer silah geliştirdiği veya gerçekten böyle bir çalışmanın olup olmadığı da cevaplanmayı bekleyen önemli araştırma konularıdır. Buna rağmen İran kamuoyunun güçlenmesi hem uluslararası ilişkilerde diplomasiye bir şans daha verilmesi ile İran Devletini hem de iç politikada temel hak ve özgürlüklerin artmasıyla İran halklarını daha da özgürleştirecektir. 


\section{Kaynakça}

Akbarzadeh, Shahram. "Democracy Promotion versus Engagement with Iran", Journal of Contemporary Asia, Cilt 41, No.3, 2011, s.470-482.

Almond, Gabriel. The American People and Foreign Policy, New York, Harcourt Press, 1950.

American Perceptions of Iranian Americans Report, Zogby International Research, Aralık 2008.

Anderson, Gordon. "Realpolitik and World Peace", International Journal on World Peace, Cilt 26, No.4, 2009, s.3-6.

Arı, Tayyar. Uluslararası Iliş̧kiler Teorileri, İstanbul, Alfa, 2002.

Ashouri, Nazgol. "Polling in Iran: Surprising Questions", 14 Mayıs 2003, https://www.washingtoninstitute. org/policy-analysis/view/polling-in-iran-surprising-questions, (Erişim Tarihi: 19 Mart 2016).

Axworthy, Michael. A History of Iran, New York, Basic Books, 2008.

Bassiouni, Cherif. "Justice and Peace: The Importance of Choosing Accountability Over Realpolitik", Case Western Reserve Journal of International Law, Cilt 35, No 191, 2003, s.191-204.

Bew, John. “The Real Origins of Realpolitik", Mart/Nisan 2014, http://nationalinterest.org/article/thereal-origins-realpolitik-9933 (Erişim Tarihi: 19 Mart 2016).

Burstein, Paul. "The Impact of Public Opinion on Public Policy", Political Research Quarterly, Cilt 56, No.1, 2003, s.29-40.

Cagaptay, Soner ve Alexander Murinson. “Good Relations between Azerbaijan and Israel”, 30 Mart 2005, http://www.washingtoninstitute.org/policy-analysis/view/good-relations-between-azerbaijan-andisrael-a-model-for-other-muslim-state (Erişim Tarihi: 19 Mart 2016).

Carr, Edward Hallett. The Twenty Years 'Crisis, 1919-1939: An Introduction to the Study of International Relations, New York, St. Martin's Press, 1946.

Chengqiu, Wu. "International Structure, Threat, and Public Opinion on Foreign Policy: Bush and Obama's Foreign Policy Turns", The Chinese Journal of International Politics, Cilt 4, No.3, 2011, s.311-343.

Chester, James. "Aristotle and the Roots of Individualism", Douglas Rasmussen, Aeon Skoble ve Douglas Den Uyl (der.), Reality, Reason, and Rights: Essays in Honor of Tibor R. Machan, New York, Lexington Books, 2011, s.13-26.

Cozette, Murielle. "Realistic Realism? American Political Realism, Clausewitz and Raymond Aron on the Problem of Means and Ends in International Politics", Journal of Strategic Studies, Cilt 27, No.3, 2004, s.428-453.

Dahrendorf, Ralf. Class and Class Conflict in Industrial Society, Stanford University Press, 1959.

Djalili, Mohammad-Reza ve Thierry Kellner. Arap Baharı Karşısında Iran ve Türkiye, İstanbul, Bilge Yayınevi, 2013.

Donnelly, Jack. Realism and International Relations, Cambridge University Press, 2000.

Donnelly, Jack. "Realism”, Scott Burchill, Andrew Linklater, Richard Devetak, Jack Donnelly, Matthew Paterson, Christian Reus-Smit ve Jacqui True (der.), Theories of International Relations, New York, Palgrave Macmillan Press, 2005, s.29-54.

Dougherty, James ve Robert Pfaltzgraff. Contending Theories of International Relations, Londra, Harper Collins Press, 1990.

Edwards, A. J. C. Nuclear Weapons, the Balance of Terror, the Quest for Peace, New York State University Press, 1986. 
Elson, Sara Beth ve Alireza Nader. What Do Iranians Think? A Survey of Attitudes on the United States, the Nuclear Program, and the Economy, Santa Monica, RAND Press, 2011.

Fan, Hongda. "China's Policy Options towards Iran", Journal of Middle Eastern and Islamic Studies, Cilt 5, No.1, 2011, s.45-60.

Farhi, Farideh. "Atomic Energy is Our Assured Right: Nuclear Policy and the Shaping of Iranian Public Opinion", Judith S. Yaphe (der.), Nuclear Politics in Iran, Washington, National Defense University Press, 2010, s.3-18.

Forde, Steven. "International Realism and the Science of Politics: Thucydides, Machiavelli and Neorealism”, International Studies Quarterly, Cilt 39, No.2, 1995, s.141-160.

Foyle, Douglas. Presidents, Counting the Public In: Public Opinion, and Foreign Policy, Columbia University Press, 1999.

Galtung, Johan. "Violence, Peace, and Peace Research", Journal of Peace Research, Cilt 6, No.3, 1969, s.167-191.

Gilpin, Robert. "The Richness of the Tradition of Political Realism”, Robert Keohane (der.), Neorealism and its Critics, Columbia University Press, 1986, s.301-321.

Gilpin, Robert. "No One Loves a Political Realist”, Security Studies, Cilt 5, No.3, 1996, s.3-26.

Goldsmith, Benjamin ve Yusaku Horiuchi. "In Search of Soft Power: Does Foreign Public Opinion Matter for U.S. Foreign Policy?”, World Politics, Cilt 64, No.3, 2012, s.555-585.

Hamaney, Ayetullah Ali. "Speaking to Iranian Officials", 10 Ekim 2006 www.leader.ir/langs/FA/index. php?p=bayan\&id=3295 (Erişim Tarihi: 19 Mart 2016).

Hardt, Michael ve Antonio Negri. “Arabs are Democracy’s New Pioneers”, 24 Şubat 2011 http://www. theguardian.com/commentisfree/2011/feb/24/arabs-democracy-latin-america (Erişim Tarihi: 19 Mart 2016).

Herzog, Michael. "Iranian Public Opinion on the Nuclear Program", 1 Haziran 2006, https://www. washingtoninstitute.org/uploads/Documents/pubs/PolicyFocus56.pdf (Erişim Tarihi: 19 Mart 2016).

Hobbes, Thomas. Leviathan, London, Green Dragon Press, 1651.

Holsti, Ole. "Public Opinion and Foreign Policy: Challenges to the Almond-Lippmann Consensus Mershon Series: Research Programs and Debates", International Studies Quarterly, Cilt 36, No.4, 1992, s.439-466.

Holsti, Ole. Public Opinion and American Foreign Policy, The University of Michigan Press, 2004.

Iranian Attitudes Report, Zogby International Research, Aralık 2013.

Kaplan, Robert. The Revenge of Geography, New York, Random House Press, 2012.

Kennan, George. American Diplomacy: 1900-1950, Dublin, Mentor Books, 1970.

Keohane, Robert. "Theory of World Politics: Structural Realism and Beyond", Robert Keohane (der.), Neo-Realism and Its Critics, Columbia University Press, 1986, s.158-203.

Kile, Shannon. Europe and Iran: Perspectives on Non-proliferation, SIPRI Research Report No. 21, Oxford University Press, 2005.

Kull, Steven. "Public Opinion in Iran", 24 Ocak 2007, http://www.worldpublicopinion.org/pipa/pdf/ apr08/Iran_Apr08_rpt.pdf (Erişim Tarihi: 19 Mart 2016).

Legro, Jeffrey. Rethinking the World: Great Power Strategies and International Order, Cornell University Press, 2005.

Lippmann, Walter. Public Opinion, New Jersey, Transaction Publishers, 1922. 
Machiavelli, Niccolò. The Prince, Oxford University Press, 2005.

McCormick, James. American Foreign Policy and Process, Boston, Wadsworth Press, 2010.

Mehmanparast, Ramin. "US, NATO After Libya Oil Reserves: Iran”, 29 Nisan 2011, http://edition. presstv.ir/detail/177586.html (Erişim Tarihi: 19 Mart 2016).

Morgenthau, Hans. Politics Among Nations, New York, Alfred Knopf Press, 1948.

Nader, Alireza. Iran After the Bomb, Santa Monica, RAND Press, 2013.

Okyar, Onur. "İran ve Arap Baharı: Çift Taraflı Aynadaki Asimetri mi?”, Uluslararası İlişkiler Dergisi, Cilt 12, No.45, 2015, s.41-62.

Page, Benjamin ve Robert Shapiro. "Effects of Public Opinion on Policy", American Political Science Review, Cilt 77, No.1, 1983, s.175-190.

Parsi, Trita. "Tharwa Feature: Iranian Public Opinion and Tehran's Nuclear Program," 4 Nisan 2005, http://www.tharwaproject.com/node/1902 (Erişim Tarihi: 19 Mart 2016).

Pettman, Ralph. "Power and Morality: A Misleading Dichotomy", Cambridge Review of International Affairs, Cilt 21, No.2, 2008, s.235-251.

Porter, Gareth. When the Ayatollah Said No to Nukes, 16 Ekim 2014, http://foreignpolicy.com/2014/10/16/ when-the-ayatollah-said-no-to-nukes/ (Erişim Tarihi: 19 Mart 2016).

Rahe, Paul. "Thucydides Critique of Realpolitik", Benjamin Frankel (der.), Roots of Realism: Philosophical and Historical Dimensions, Londra, Frank Cass Press, 1996, s.105-141.

Rakel, Eva Patricia. "Iranian Foreign Policy Since The Iranian Islamic Revolution: 1979-2006," Perspectives on Global Development and Technology, Cilt 6, No.1, 2007, s.159-187.

Rakel, Eva Patricia. "The Political Elite in the Islamic Republic of Iran: From Khomeini to Ahmadinejad”, Comparative Studies of South Asia, Africa and the Middle East, Cilt 29, No.1, 2009, s.105-125.

Ruhani, Hasan. "Beyond the Challenges Facing Iran and the IAEA Concerning the Nuclear Dossier", 30 Eylül 2005, http://www.iranwatch.org/sites/default/files/rahbord-rohani-093005_0.pdf (Erişim Tarihi: 19 Mart 2016).

Sadjadpour, Karim. “On Iranian Public Support for Tehran's Nuclear Ambitions”, 13 Mart 2006, http:// www.cfr.org/iran/sadjadpour-iranian-public-support-tehrans-nuclear-ambitions/p10100 (Erişim Tarihi: 19 Mart 2016).

Sandole, Dennis. "Complexity and Conflict Resolution", Neil Harrison (der.), Complexity in World Politics: Concepts and Methods of a New Paradigm, Albany, State University of New York Press, 2006, s.43-71.

Schwarzenberger, Georg. Power Politics: An Introduction to the Study of International Relations and Post-War Planning, London, J. Cape Press, 1941.

Shahghasemi, Ehsan, Ray Heisey ve Goudarz Mirani. "How do Iranians and U.S. Citizens Perceive Each Other: A systematic Review”, Journal of Intercultural Communication, No.27, 2011.

Skinner, Quentin. Machiavelli: A Very Short Introduction, Oxford University Press, 2001.

Sobel, Richard. The Impact of Public Opinion on U.S. Foreign Policy since Vietnam, Oxford University Press, 2001.

Soroka, Stuart. "Media, Public Opinion, and Foreign Policy", The International Journal of Press/ Politics, Cilt 8, No.1, 2003, s.27-48.

Spegele, Roger. Political Realism in International Theory, Cambridge University Press, 1996.

Surowiecki, James. The Wisdom of Crowds, New York, Anchor Books, 2005.

Rindermann, Heiner, Carmen Flores Mendoza ve Michael Woodley. "Political orientations, intelligence and education", Intelligence, Cilt 40, No.2, 2012, s.217-225. 
Terror Free Tomorrow. "Polling Iranian Public Opinion: An Unprecedented Nationwide Survey of Iran”, Washington, Haziran 2007.

Thucydides. The Peloponnesian War, Oxford University Press, 2009.

Waltz, Kenneth. Theory of International Politics, Boston, Addison-Wesley Publishing, 1979.

Warner, Carolyn ve Stephen Walker. "Thinking about the Role of Religion in Foreign Policy: A Framework for Analysis," Foreign Policy Analysis, Cilt 7, No.1, 2011, s.113-135.

Wilson, Ernest. "Hard Power, Soft Power, Smart Power", The Annals of the American Academy of Political and Social Science, Cilt 616, No.1, 2008, s.110-124.

Wittkopf, Eugene, Christopher Jones ve Charles Kegley. American Foreign Policy: Pattern and Process, Belmont, Thomson Wadsworth Press, 2004.

World Public Opinion, "Poll of Iranians and Americans," 27 Ocak 2008.

Yost, David. "Analysing International Nuclear Order", International Affairs, Cilt 83, No.3, 2007, s.549-574

Younis, Mohamed. Iranians Feel Bite of Sanctions, Blame U.S., Not Own Leaders, 7 Şubat 2013, http:// www.gallup.com/poll/160358/iranians-feel-bite-sanctions-blame-not-own-leaders.aspx （Erişim Tarihi: 19 Mart 2016).

Woodley, Michael. "Are High-IQ Individuals Deficient in Common Sense? A critical examination of the 'clever sillies' hypothesis", Intelligence, Cilt 38, 2010, s.471-480. 